\title{
Enzymatically Activated Glyco-Prodrugs of Doxorubicin Synthesized by a Catalysis-Free Diels-Alder Reaction
}

\author{
David Bliman ${ }^{1,2}$, Martine Demeunynck ${ }^{2}$, Pierre Leblond $^{3}$, Samuel Meignan ${ }^{3}$, Isabelle \\ Bausanne $^{2}$, Sebastien Fort ${ }^{1}$ \\ ${ }^{1}$ Univ. Grenoble Alpes, CNRS, CERMAV, 38000 Grenoble, France \\ ${ }^{2}$ Univ. Grenoble Alpes, CNRS, DPM, 38000 Grenoble, France. \\ ${ }^{3}$ Tumorigenesis and Resistance to Treatment Unit, Centre Oscar Lambret, Lille, FRANCE \\ INSERM U908, IRCL, Lille, FRANCE
}

\begin{abstract}
The severe side effects associated with the use of anthracycline anticancer agents continues to limit their use. Herein we describe the synthesis and preliminary biological evaluation of three enzymatically activatable doxorubicin-oligosaccharide prodrugs. The synthetic protocol allows late stage variation of the carbohydrate and is compatible with the use of disaccharides such as lactose as well as more complex oligosaccharides such as xyloglucan oligomers. The enzymatic release of doxorubicin from the prodrugs by both protease (plasmin) and human carboxylesterases (hCE1 and 2) was demonstrated in vitro and the cytotoxic effect of the prodrugs were assayed on MCF-7 breast cancer cells.
\end{abstract}

\section{Introduction}

Despite continuing efforts in oncogenic drug development, surgery remains an important form of treatment for solid tumours. This approach generally includes a postoperative drug therapy to prevent reoccurrence of the tumour. Currently used drugs for such adjuvant treatment include the anthracycline antibiotic Doxorubicin (Dox). ${ }^{1}$ While the details of the mechanism of action of anthracyclines are still under investigation, ${ }^{2}$ the cytotoxic activity is suggested to be a result of intercalation with $\mathrm{DNA}^{3}$ and inhibition of topoisomerase II. ${ }^{4}$ Due to the unselective nature of the anthracyclines, treatments are often associated with severe side effects such as cardiac toxicity. ${ }^{5}$ This has led to extensive efforts in reducing the systemic toxicity of Dox and other anticancer drugs by different types of prodrug approaches. ${ }^{6}$ In these strategies, the drug is modified in a way that minimizes its off target activity while allowing activation at the intended site. Prodrug approaches for Dox include both non-covalent and covalent modifications. A notable example of noncovalent prodrugs of Dox is the inclusion of Dox in liposomes. ${ }^{7}$ Lipid encapsulation of the drug contributes to decreasing toxic side effects, since liposomes can penetrate endothelial lesions found in the neovasculature of tumors but not in normal blood vessels. FDA approved pegylated and non-pegylated liposomal Dox formulations, namely Doxil $^{\circledR}$ and Myocet ${ }^{\circledR}$ respectively for treating Aids related Kaposi's sarcoma, ovarian cancer and breast cancer. ${ }^{8}$ The covalent approach typically involves modification either on the primary amine to form carbamates, ${ }^{9,}, 10$ or on the ketone functionality by forming hydrazones. The $\mathrm{pH}$ sensitive hydrazone can be cleaved in the acidic microenvironment of the tumour ${ }^{11}$ and the carbamate can be attached to an enzymatically hydrolyzable oligopeptide. Both approaches have been used to design cell-targeting prodrugs through the conjugation to antibodies. ${ }^{12,13}$ The diverse functionalities of carbohydrates make them potential candidates for use in prodrugs. Amazingly, there are very few examples of glycosylated prodrugs reported in the literature to date. Carbohydrates have mainly been used as a triggering group for the drug release since they can be hydrolyzed by the glycosidases overexpressed by cancer cells. The most prominent example is that of glucuronic acid ${ }^{14,15}$ that is degraded by $\beta$-glucuronidase 
which have been found at high levels in tumour tissue. ${ }^{16}$ Assets of carbohydrates are not restricted to their biocompatibility and biodegradability. They also present a large range of remarkable biological and physico-chemical properties. Carbohydrate-protein interactions play an important role for regulating biochemical processes, such as cell differentiation, proliferation and adhesion, inflammation, and immune response. The feasibility of using carbohydrate ligands to target protein receptors, termed 'glycotargeting', was first demonstrated in $1971 .{ }^{17}$ Since then the potential of using carbohydrates to design drug-delivering systems has been made clear. However, small molecule drugs, no matter how heavily glycosylated they are, have the potential to pass into the kidneys, through glomerular filtration, and be rapidly cleared. For this reason, much effort are devoted to designing macromolecular glycosylated carriers and there is little work on the development of such glycotargeting prodrugs. ${ }^{18}$

Carbohydrates also interact with other carbohydrates through the establishment of an extensive network of hydrogen bondings and of hydrophobic interactions. In particular, polysaccharidepolysaccharide interactions play an important role in the control of the architecture of animal and plant cells. Cellulose and xyloglucan $(\mathrm{XG})$ assemble to form the cellulose/XG network, which is considered the dominant load-bearing structure in the growing cell walls of nongraminaceous land plants. In a biomimetic approach, Brumer et al. reported the efficient modification of cellulosic materials with different molecules including enzymes and the cell adhesion peptide RGD through anchorage of xyloglucan-based glycoconjugates at their surface. ${ }^{19,20}$ A particular advantage of such non-covalent modification is to circumvent the limited reactivity of insoluble cellulose and to preserve the fibre's integrity.

In the present work, we report the synthesis and preliminary biological evaluation of new enzymatically activated Dox glyco-prodrugs aimed at being administered in situ at the tumor site after resection. The carbohydrates, lactose and XGO, the oligosaccharide-repeating unit of xyloglucan, were chosen to address two specific roles. Lactose binds to galectins, a family of $\beta$-galactoside binding proteins associated with tumour malignancy. ${ }^{21,}{ }^{22}$ Interaction between lactose and galectins is expected to decrease diffusion of the glyco-prodrug and to hamper its rapid clearance thus allowing a sustained release of the Dox when administered in solution. On the other hand, the use of XGO could allow the immobilization of the Dox prodrug onto cellulosic wound dressing. The synthetic route consisted in the conjugation of furan-modified carbohydrates and maleimide-activacted Dox by a metal free Diels Alder cycloaddition (Figure 1). We have previously used thiol-maleimide Michael-type addition ${ }^{23}$ coupling for conjugation of reducing-end functionalized carbohydrates. While being a metal-free reaction, this reaction requires handling sulfurylated molecules susceptible to oxidation. Another type of ligation reaction is the Diels-Alder cycloaddition. ${ }^{24}$ The inverse electron demand Diels-Alder reaction (iEDDA) between 1,2,4,5-tetrazines and olefins has increasingly gained importance in chemical biology as a fast and metal-free bioorthogonal ligation reaction. ${ }^{25,}{ }^{26}$ Furan-maleimide cycloaddition is another type of popular Diels-Alder reaction having the advantage of using widely available reactants. This conjugation method recently allowed us to prepare glycosylated chromatographic matrices for the capture of carbohydrate-binding proteins. ${ }^{27}$ This reaction allows catalysis-free introduction of the carbohydrate part in water or in organic solvent at a late stage, avoiding extensive carbohydrate protecting group strategies. The presence of a peptide- or ester-containing spacer arm between the maleimide group and the anthracycline should allow the enzymatic release of the Dox by endogenous peptidases or esterases. 


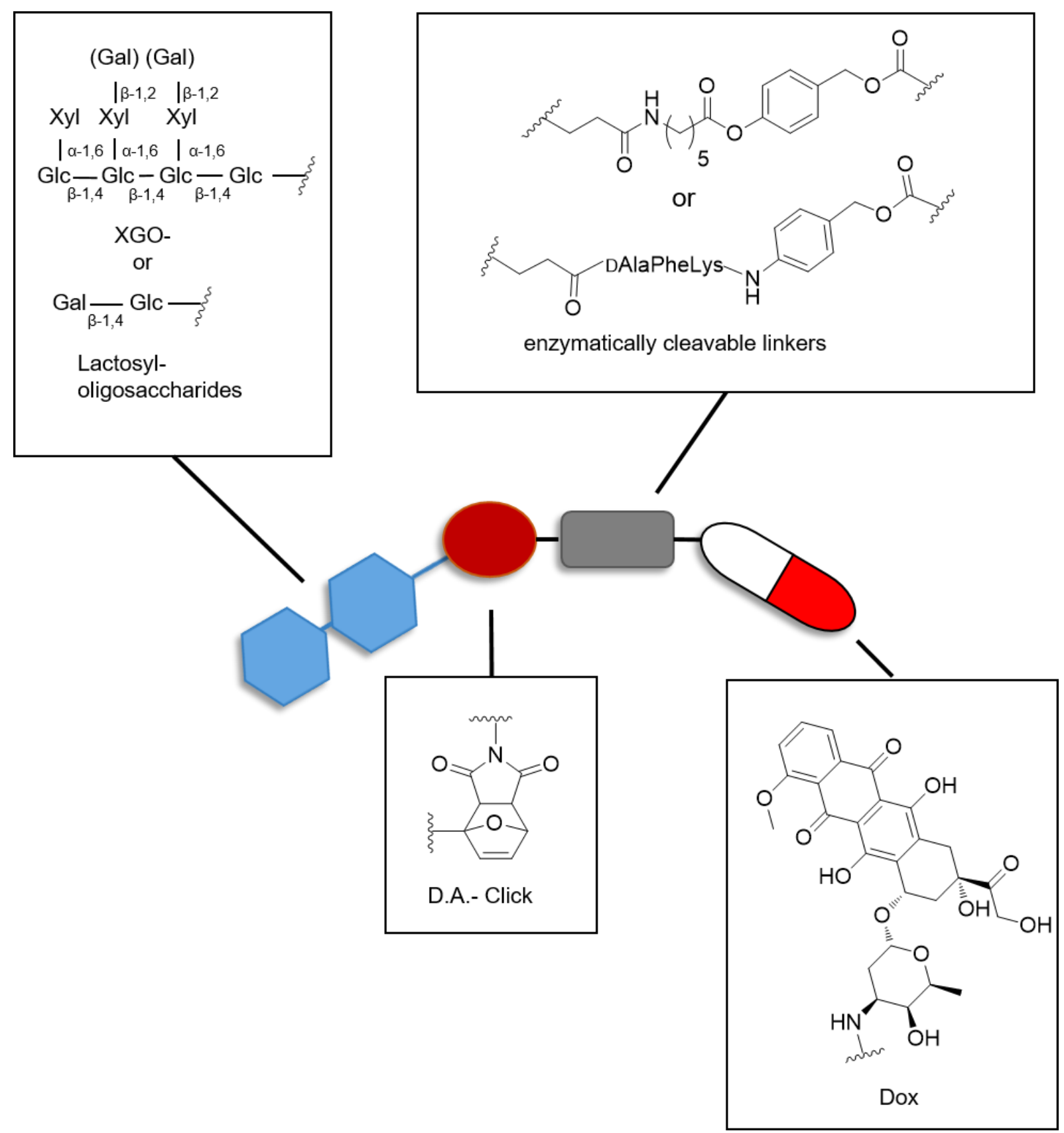

Figure 1. General scheme of the enzymatically activated glyco-prodrugs of Dox. D.A.=Diels Alder.

\section{Results and Discussion}

\section{Synthesis}

We sought to obtain two types of glyco-prodrugs of Dox with different activating mechanisms. Our first strategy was to link the drug to the carbohydrate part through ester formation, permitting the release of the drug by esterases, particularly human carboxylesterase 2 that is commonly expressed in tumor tissues. ${ }^{28}$ The ester functionality is linked to the primary amine of Dox by a $p$-aminobenzyl alcohol (PABA) spacer. Hydrolysis of the ester bond will initiate a cascade reaction of this so-called self-immolative spacer, first reported by Katzenellenbogen, ${ }^{29}$ ultimately resulting in the release of Dox. Our second strategy sought to enable Dox release by specific proteases. To this goal, we chose a tripeptide linker (D-Ala-Phe-Lys) ${ }^{30}$ known to be cleaved by plasmin, which has been identified as a potential target protease for prodrug 
activation of cancer drugs. ${ }^{31}$ This linker has previously been used in combination with the PABA self-immolative linker in the synthesis of Dox $^{32}$ and Dox derivative prodrugs. ${ }^{33}$ The latter were shown to be stable in human plasma and poorly membrane permeable, thereby limiting activation to locally secreted proteolytic activity and reducing the likelihood of severe side effects.

Starting with the linker drug end of the prodrugs, the synthesis of the maleimidyl ester linked Dox (MalEsterDox 1) was performed starting from $\omega$-aminocapronic acid 2 (Scheme 1). The five-carbon spacer length provided by the use of $\omega$-aminocapronic acid has previously been reported for enzymatically cleaved prodrugs of Dox. ${ }^{34}$<smiles>CC(NC(=O)C(C)(C)C)C(=O)Oc1ccc(C=O)cc1</smiles>

Scheme 1. Synthesis of 1. a) (Boc) $)_{2} \mathrm{O}$ (1.1 equiv.) in $\mathrm{NaOH}($ aq.), 1,4-dioxane 1:2, 16 h, $89 \%$. b) DCC (1 equiv.), DMAP (20 mol\%), p-methoxybenzaldehyde (0.95 equiv.) in $\mathrm{CH}_{2} \mathrm{Cl}_{2}, 0{ }^{\circ} \mathrm{C}$ to r.t., $21 \mathrm{~h}, 86 \%$. c) $\mathrm{NaBH}_{4}\left(0.95\right.$ equiv.) in $\mathrm{CF}_{3} \mathrm{CH}_{2} \mathrm{OH}, 0{ }^{\circ} \mathrm{C}, 1 \mathrm{~h} 20$ min, $90 \%$. d) TFA: $\mathrm{CH}_{2} \mathrm{Cl}_{2}$ $1: 1$, r.t. $20 \mathrm{~min}$, then e) 3-( $N$-maleimido)propionic acid (1.1 equiv.), DCC (1.1 equiv.), NMM (3 equiv.) in $\mathrm{CH}_{2} \mathrm{Cl}_{2}, 0{ }^{\circ} \mathrm{C}$ to r.t., $17 \mathrm{~h}, 51 \%$ over 2 steps. f) Bis(4-nitrophenyl) carbonate (1.5 equiv.), DIPEA (3 equiv.) in $\mathrm{CH}_{2} \mathrm{Cl}_{2}$, r.t., 4 h, $70 \%$. g) Dox ${ }^{*} \mathrm{HCl}$ (0.9 equiv.), $\mathrm{Et}_{3} \mathrm{~N}$ (2 equiv.) in DMF, r.t., 22h, $59 \%$.

tert-Butyloxycarbonyl ( $t \mathrm{Boc})$ protection of the amine with di-(tert-butyl)dicarbonate in the presence of sodium hydroxide $(\mathrm{NaOH})$ gave carboxylic acid 3 which was coupled with $p$ hydroxybenzaldehyde by Steglich esterification to give ester 4 in $86 \%$ yield. The next step was the reduction of the aldehyde to the corresponding alcohol. Performing the reduction with $\mathrm{NaBH}_{4}$ in THF at $0^{\circ} \mathrm{C}$ resulted in multiple products as observed by TLC already after 15 min. Trifluoroethanol has previously been reported as a co-solvent for $\mathrm{NaBH}_{4}$ reductions. ${ }^{35,36}$ Reduction of aldehyde 4 with $\mathrm{NaBH}_{4}$ in trifluoroethanol at $0^{\circ} \mathrm{C}$ resulted in full conversion after one hour and allowed us to isolate hydroxyl $\mathbf{5}$ in high yield (90\%). Next, the maleimide (Mal) 
was introduced by $t$ Boc deprotection with trifluoroacetic acid (TFA) followed by amidation with 3-maleimidopropionic acid in the presence of dicyclohexylcarbodiimide (DCC) and $\mathrm{N}$ methylmorpholine (NMM). MalEsterOH 6 was isolated in $51 \%$ over two steps. To introduce the carbamate-linked Dox, the hydroxyl of $\mathbf{6}$ was converted to a mixed anhydride by reaction with bis $p$-nitrophenoxyanhydride in the presence of $N, N$-diisopropylethylamine (DIPEA) in dichloromethane (DCM) (70\% yield). Stirring 7 in dimethylformamide (DMF) at room temperature (r.t.) with Dox in the presence of triethylamine resulted in MalEsterDox 1 in 59\% yield.

The synthesis of the peptide-linked glyco-prodrug started with the synthesis of the D-Ala-PheLys tripeptide. The synthesis of this tripeptide has previously been described both in solution ${ }^{32}$ and on solid support. ${ }^{33}$ Our synthetic strategy for the Dox tripeptide motif started from $N_{\alpha^{-}}$ Fmoc- $N_{\varepsilon}$-Alloc-Lysine $\mathbf{8}$ which was activated by iso-butylchloroformate and functionalized with $p$-aminobenzylalcohol to give 9 in $72 \%$ yield (Scheme 2).

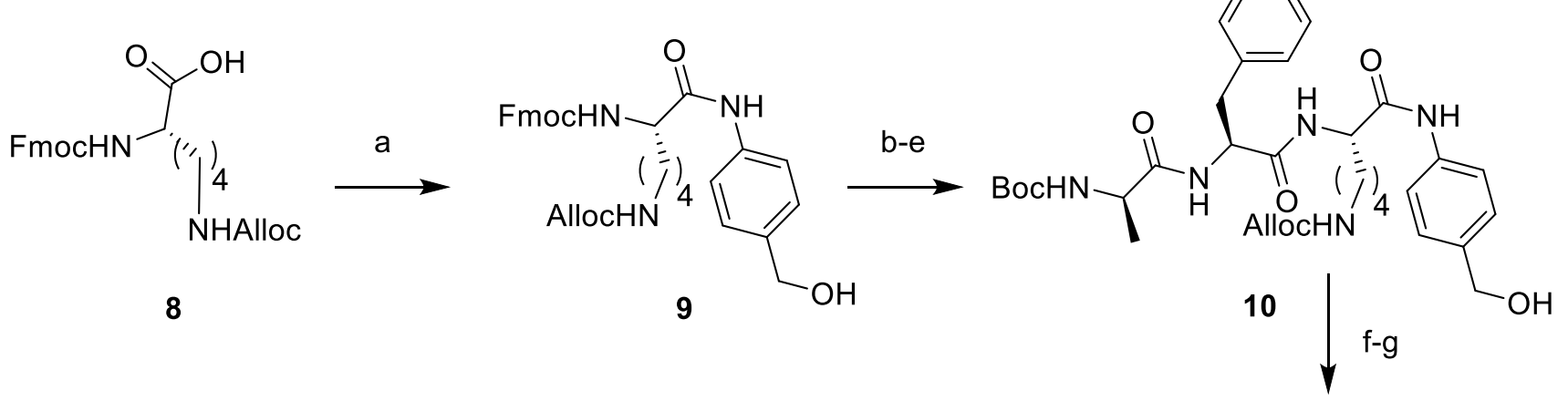

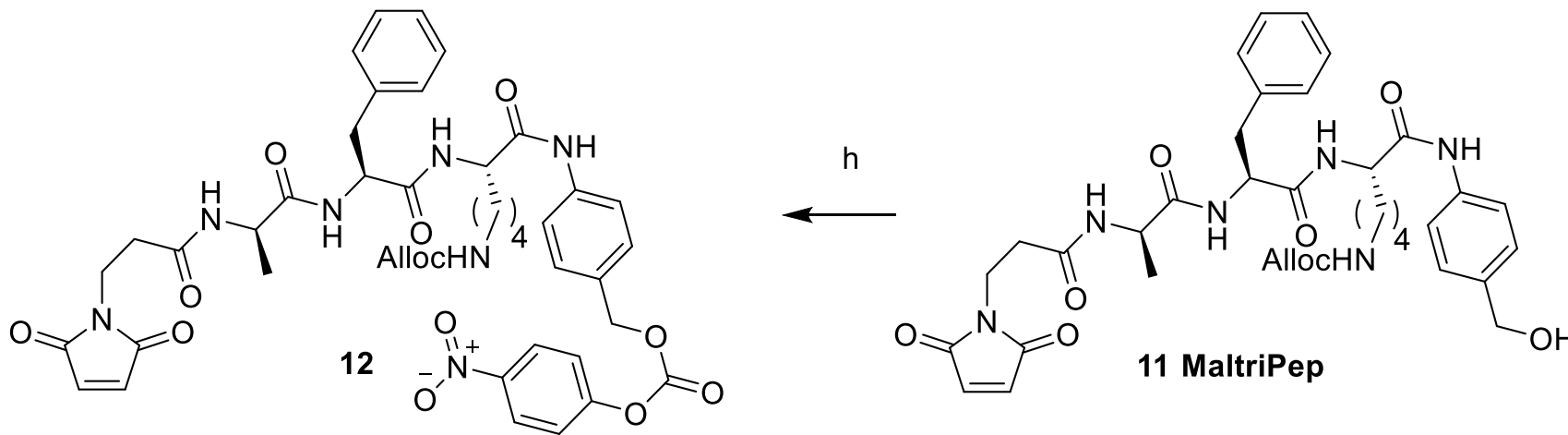

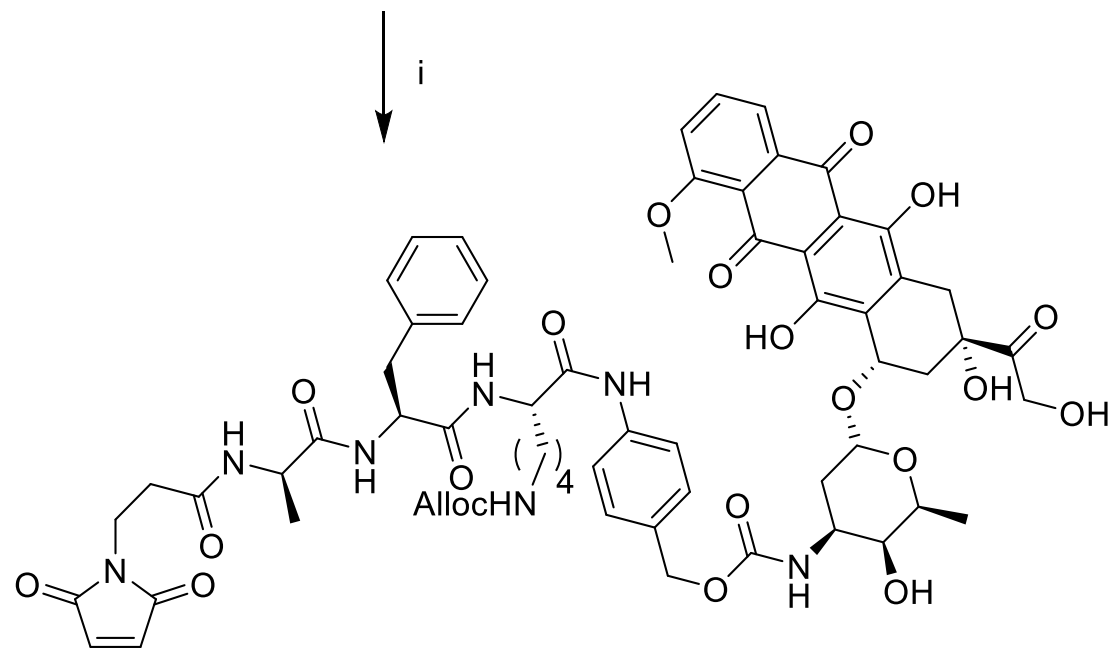

13 MaltriPepDox 
Scheme 2. Synthesis of 13. a) ibutylchloroformate (1.1 equiv.), $p$-aminobenzylalchohol (1.2 equiv.), NMM (2.3 equiv.) in THF, $-40{ }^{\circ} \mathrm{C}, 72 \%$. b) 1,4-dioxane: $\mathrm{MeOH}$ : $2 \mathrm{M} \mathrm{NaOH}$ (aq.), r.t., 20 min, then c) DMTMM (1 equiv.), FmocPheOH (1 equiv.), NMM (1.1 equiv.) in $\mathrm{CH}_{3} \mathrm{CN}$, r.t., 19h, then d) 1,4-dioxane:MeOH: $2 \mathrm{M} \mathrm{NaOH}$ (aq.), r.t., $20 \mathrm{~min}$, then e) DMTMM (1 equiv.), Boc-D-AlaOH (1 equiv.), NMM (1.1 equiv.) in $\mathrm{CH}_{3} \mathrm{CN}$, r.t., $14 \mathrm{~h}, 47 \%$ over 4 steps. f) TFA: $\mathrm{CH}_{2} \mathrm{Cl}_{2}$ 0.8:1, r.t., $15 \mathrm{~min}$, then g) DMTMMBF 4 (1.1 equiv.), 3-( $N$-maleimido)propionic acid (1.2 equiv.), NMM (1.1 equiv.) in $\mathrm{CH}_{3} \mathrm{CN}$, r.t., $22 \mathrm{~h}, 43 \%$ over two steps. h) bis(4-nitrophenyl) carbonate (5 equiv.), DIPEA (3 equiv.) in DMF, r.t., 46 h then i) Dox* $\mathrm{HCl}$ (0.9 equiv.), $\mathrm{Et}_{3} \mathrm{~N}$ (2 equiv.) in DMF, r.t., $24 \mathrm{~h}, 75 \%$.

The tripeptide linker was synthesized by solution phase peptide synthesis with $\mathrm{N}$-Fmoc protected amino acids using 4-(4,6-Dimethoxy-1,3,5-triazin-2-yl)-4-methylmorpholinium tetrafluoroborate $\left(\mathrm{DMTMMBF}_{4}\right)^{37,38}$ as coupling reagent followed by deprotection with $\mathrm{NaOH}$ (aq.). The tripeptide $\mathbf{1 0}$ was obtained in $47 \%$ yield over 4 steps. The maleimide was introduced in a similar way as for the previously described linker by TFA deprotection of the $t$ Boc followed by amidation to give MaltriPep 11 in $43 \%$ yield over two steps. The hygroscopic nature of the tripeptide in combination with the risk of hydrolyzing the maleimide made it necessary to thoroughly dry (high vacuum pump) and store all following intermediates below $-15^{\circ} \mathrm{C}$. As for the ester-based linker described above, the hydroxyl function of $\mathbf{1 1}$ was activated as a mixed anhydride by reaction with five equivalents of bis $p$-nitrophenoxy carbonate in the presence of DIPEA. The mixed anhydride $\mathbf{1 2}$ was isolated by precipitation in diethyl ether and was used in the following substitution without further purification. Stirring 12 with Dox and $\mathrm{Et}_{3} \mathrm{~N}$ in DMF at room temperature gave MaltriPepDox 13 in $75 \%$ yield and high purity as confirmed by HPLC (see SI).

The next step was the conjugation of the drug-linker part with the carbohydrate moiety. The furfuryl-functionalized carbohydrates were obtained through a two steps method for synthesizing $N$-glycosylamides first introduced by Lokhoff et al. ${ }^{39}$ and utilized in our group to synthesize a range of reducing-end functionalized oligosaccharides. ${ }^{23}, 27$ The unprotected carbohydrate was stirred in neat furfurylamine for 72 hours to afford a transient glycosylamine that was made non-hydrolyzable by acylation of the nitrogen with acetic anhydride. The synthesis of furfuryl-lactose $\mathbf{1 4}$ was previously published for the production of conjugatable glycosaminoglycans. ${ }^{40}$ The furfuryl-XGO $\mathbf{1 5}$ was synthesized for this study from the oligosaccharide-repeating unit of tamarind seed xyloglucan. First, the XGO repeating unit, which consists in a mixture of hepta-, octa- and nona-saccharides in a ratio of 15/35/50, was obtained quantitatively by enzymatic hydrolysis of the polysaccharide as reported previously. ${ }^{41}$ The furfuryl-XGO was then obtained in $90 \%$ yield following the same protocol as for lactose. The conjugation of MalEsterDox 1 with furfuryl-lactose 14 in DMF and water $(1: 1)$ at $37{ }^{\circ} \mathrm{C}$ gave LacEsterDox 16 in high yield (91\%, Scheme 3). The XGOEsterDox prodrug 17 was prepared under similar reaction conditions but was isolated in 35\% yield only after purification on reverse phase $\mathrm{C}_{18}$ cartridges. The yield is lower than typically observed in this type of cycloaddition and is partly explained by extensive chromatographic purification. The reaction conditions and the purification procedure should be optimized but sufficient quantities for drug release and cell toxicity studies were isolated and no attempt to improve the yield have been done so far. 

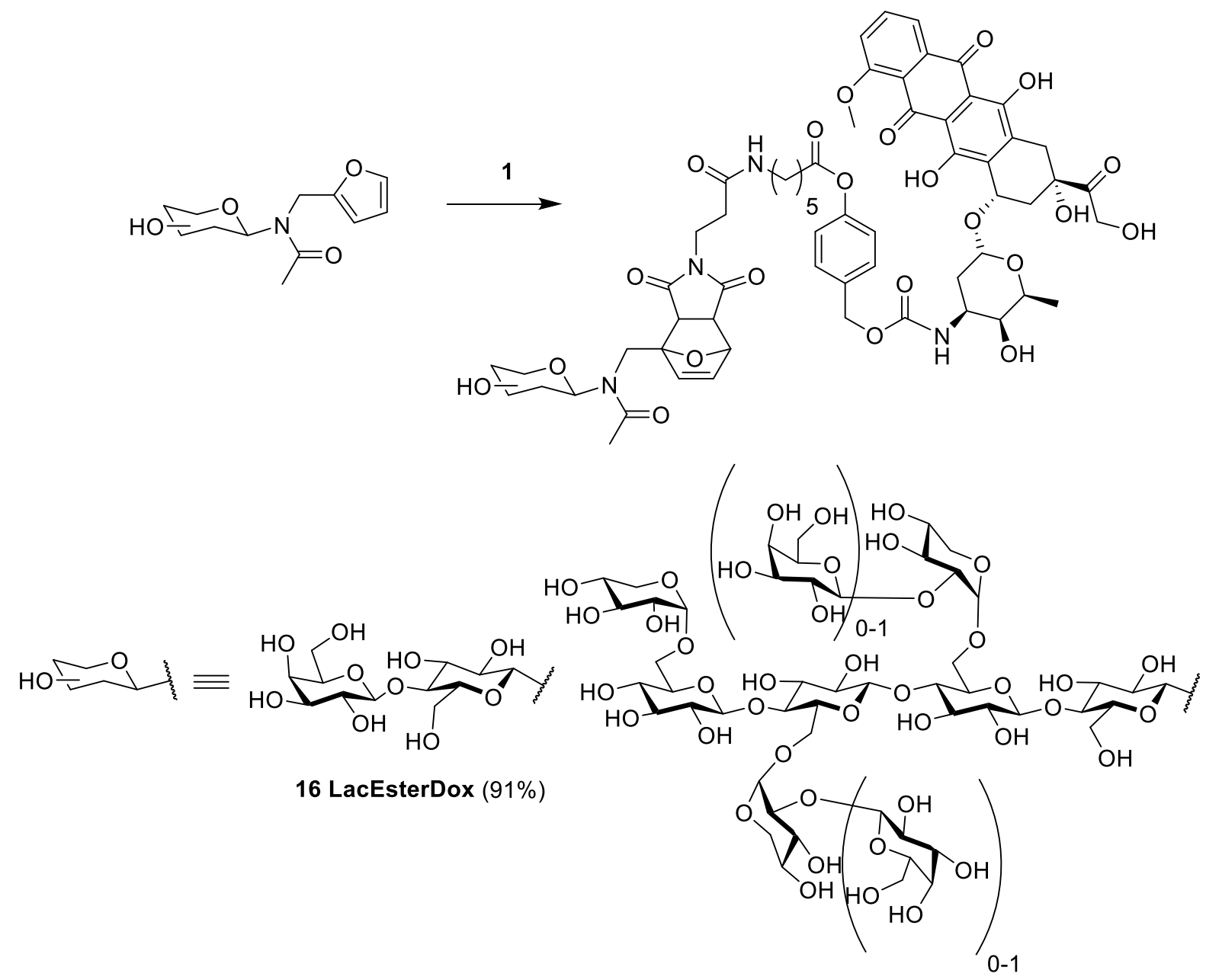

17 XGOEsterDox (35\%)

Scheme 3. Synthesis of $\mathbf{1 6}$ and 17. DMF: $\mathrm{H}_{2} \mathrm{O} 1: 1,37^{\circ} \mathrm{C}, 3$ and 4 days for $\mathbf{1 6}$ and 17, respectively.

To obtain the tripeptide linked glyco-prodrug (LactriPep(Alloc)Dox) (18, Scheme 4), 13 and furfuryl-lactose 14 were stirred in a mixture of DMF and $\mathrm{H}_{2} \mathrm{O}(2: 1)$ at $37^{\circ} \mathrm{C}$ for 7 days. $18(57 \%$ yield) was isolated in high purity as confirmed by HPLC (see SI) after purification on silica eluting with $10 \%$ water in acetonitrile. 


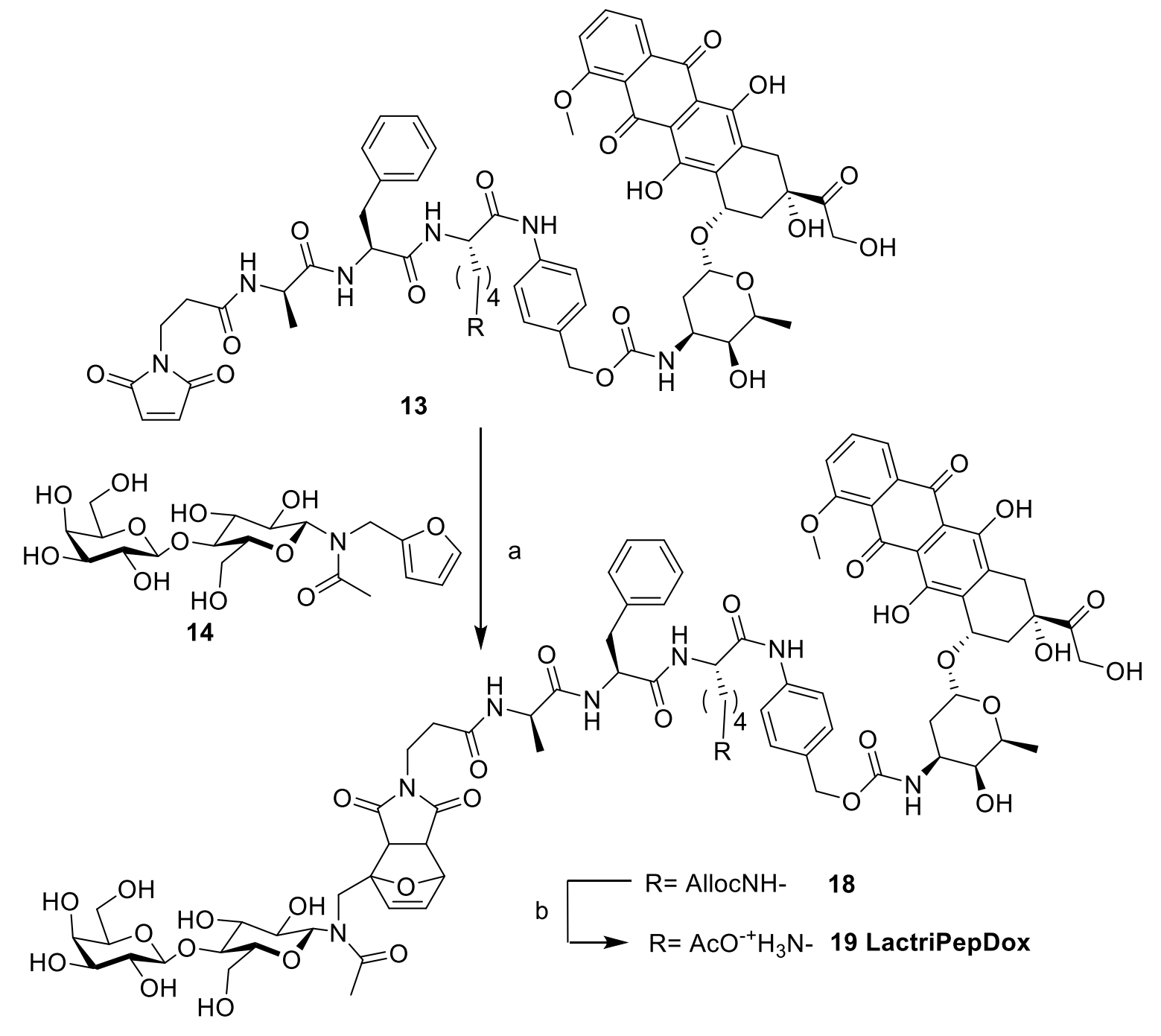

Scheme 4. Synthesis of 19. a) DMF: $\mathrm{H}_{2} \mathrm{O} 2: 1,37^{\circ} \mathrm{C}, 7$ days, 58\%. b) $\mathrm{Pd}\left(\mathrm{PPh}_{3}\right)_{4}$ (1.2 equiv.), $\mathrm{CH}_{2} \mathrm{Cl}_{2}: \mathrm{AcOH}$ 5:1, r.t., $30 \mathrm{~min}, 59 \%$.

The last step of removal of the Alloc protecting group from the lysine side chain was more tricky. Commonly used conditions for Alloc removal include catalytic amounts of $\mathrm{Pd}^{0}$ in the presence of an allyl scavenger such as morpholine, tributyltin hydride or silane. ${ }^{42}$ However, using catalytic amounts of $\mathrm{Pd}\left(\mathrm{PPh}_{3}\right)_{4}(20 \mathrm{~mol} \%)$ and morpholine as allyl scavenger, we were unable to isolate the desired product, only observing degradation on TLC. Eliminating the scavenger and running the reaction with equimolar amount of $\mathrm{Pd}\left(\mathrm{PPh}_{3}\right)_{4}$ in a mixture of acetic acid and dichloromethane as described by Barthel et al. ${ }^{33}$ gave the desired product 19 (LactriPepDox) in 59\% yield after precipitation from diethyl ether.

\section{Enzymatic release of Dox from glyco-prodrugs}

To confirm the intended enzymatic release of Dox, the LactriPepDox $19(100 \mu \mathrm{M})$ was incubated in vitro in the presence $15 \mu \mathrm{g} / \mathrm{ml}$ of human plasmin at $37^{\circ} \mathrm{C}$ in phosphate buffer $(\mathrm{pH}$ 7.5). The disappearance of prodrug and appearance of Dox was followed by HPLC (Figure 2). We first checked the stability of the prodrugs in these conditions in the absence of plasmin (no release after up to $25 \mathrm{~h}$ at $37^{\circ} \mathrm{C}$, data not shown). In the presence of plasmin, nearly full conversion of the prodrug into Dox was achieved after $2 \mathrm{~h}$. 


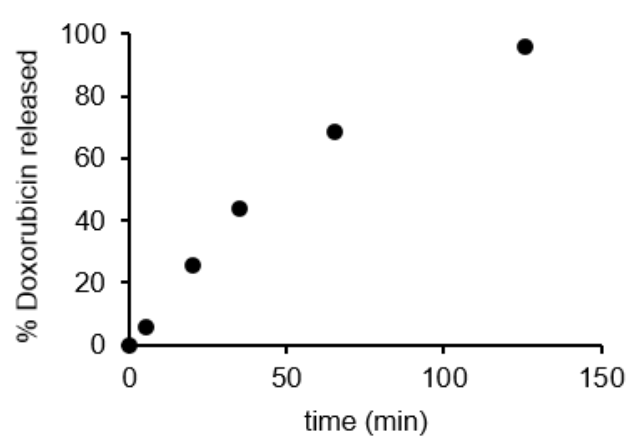

Figure 2. In vitro protease mediated release of Dox $(\bullet)$ from LactriPepDox $19(100 \mu \mathrm{M})$ using $15 \mu \mathrm{g} / \mathrm{ml}$ plasmin in phosphate buffer $(\mathrm{pH} 7.5)$ at $37^{\circ} \mathrm{C}$.

The release of Dox from LacEsterDox 16 was performed in $50 \mathrm{mM}$ Tris buffer (pH 7.4). Incubating $16(100 \mu \mathrm{M})$ at $37^{\circ} \mathrm{C}$ in the presence of human carboxylesterase 1 (hCE1) (100 $\mu \mathrm{g} / \mathrm{ml})$ resulted in only minor $(\sim 5 \%)$ release of Dox after $22 \mathrm{~h}$ (Figure 3 ).

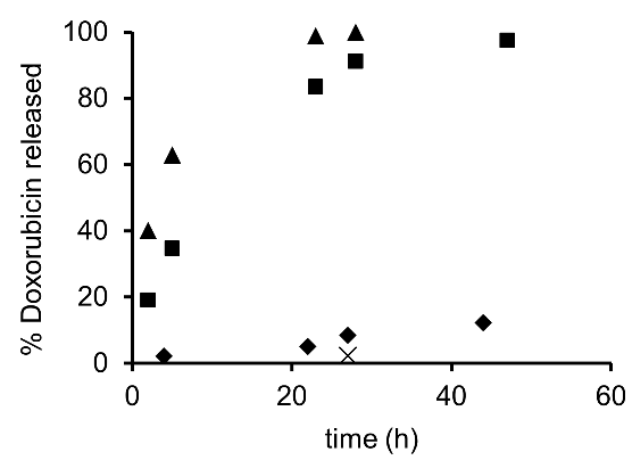

Figure 3. In vitro esterase mediated release of Dox using $100 \mu \mathrm{g} / \mathrm{ml}$ esterase in $50 \mathrm{mM}$ Tris buffer (pH 7.4) at $37{ }^{\circ} \mathrm{C}$ from LacEsterDox 16 with hCE2( $\left.\boldsymbol{\Delta}\right)$, from LacEsterDox 16 with hCE1( $\bullet$ ), from XGOEsterDox 17 with hCE2( $\mathbf{a})$ and LacEsterDox 16 without enzyme (x). The values for hCE2 measurements are mean values of duplicate experiments.

In contrast, incubating 16 with human carboxylesterase 2 (hCE2) under identical conditions resulted in full release after 23h. The rate of hydrolysis for XGOEsterDox 17 was slightly slower than for $\mathbf{1 6}(83 \%$ after $23 \mathrm{~h})$, possibly owing to the steric effect of the larger oligosaccharide. Nevertheless, after $48 \mathrm{~h}, 98 \%$ of $\mathbf{1 7}$ had been hydrolyzed. The difference in rate between hCE1 and hCE2 could be explained by the presence of a phenyl on the alcohol side since hCE2 is known to hydrolyze esters with bulkier alcohol groups at a higher rate than hCE1. ${ }^{43}$ As was observed for the tripeptide prodrug 19, incubating the ester prodrug (LacEsterDox) in the absence of esterase resulted in less than 2\% Dox after $27 \mathrm{~h}$ (data not shown). These results confirm that Dox is enzymatically released from prodrugs 16, 17 and 19 and that these three prodrugs are stable in the buffers in absence of enzyme.

\section{Biological evaluation}

As a preliminary test for verifying the biological interest of the prodrugs, the cytotoxicity of compounds 16, 17 and 19 was assayed on MCF-7 breast cancer cells and compared with that of free Dox (Table 1). 


\begin{tabular}{cc} 
Compound & $\mathrm{IC}_{50}(\mu \mathrm{M})$ \\
\hline $\mathbf{1 6}$ & $0.51 \pm 0.07$ \\
$\mathbf{1 7}$ & $0.31 \pm 0.15$ \\
$\mathbf{1 9}$ & $1.11 \pm 0.11$ \\
Dox & 0.53 \\
\hline
\end{tabular}

Table 1. Inhibition of MCF-7 breast cancer cell growth by the glyco-prodrugs and free Dox as reference. $\mathrm{IC}_{50}$ values were calculated as the concentration of compound needed to reduce cell growth by $50 \%$. Values are reported as mean \pm the standard deviation (SD) of triplicate measurements.

The plasmin-activated prodrug 19 displayed a slightly higher ( 2 fold) $\mathrm{IC}_{50}$ compared to Dox while the esterase activated prodrugs $\mathbf{1 6}$ and $\mathbf{1 7}$ showed IC $_{50}$ values similar to that of the parent drug. Since it has been previously shown that protection of the primary amine of Dox results in a significant decrease in activity, ${ }^{44}$ these results are a clear indication of Dox release from prodrugs 16, 17 and 19 in presence of the MCF-7 cells. One would have probably expected a more pronounced difference between the $\mathrm{IC}_{50}$ of the ester and amide prodrugs as plasmin (which is not over-expressed on MCF-7 cells) has not been added in the cell culture medium), and further experiments are now required to study the mode of action of the glyco-prodrugs. Nevertheless, the similar IC $_{50}$ obtained for XGOEsterDox 17 and LacEsterDox 16 are very encouraging since they show that the release of Dox is not dependent on the size and therefore steric hindrance of the oligosaccharide moiety. In a forthcoming work, we wish to implement the use xyloglucan glycoconjugates to the development of drug-functionalized cellulosic biomaterials.

\section{Conclusion}

We have synthesized a small series of enzymatically activatable glyco-prodrugs of Dox. We demonstrated the release of the drug by enzymatic cleavage in vitro and in cellulo on MCF-7 cancer cells, as the prodrugs and Dox itself display similar $\mathrm{IC}_{50}$. The late stage metal free cycloaddition used to ligate the oligosaccharide and the drug allows this methodology to be used with different oligosaccharides and potentially with different drugs. Current work in our groups includes extending this ligation to synthesize prodrugs of other drug classes.

\section{Experimental procedures}

\section{General considerations}

All commercial chemicals were used without prior purification. ${ }^{1} \mathrm{H}$ - and ${ }^{13} \mathrm{C}-\mathrm{NMR}$ spectra were obtained at 400 and $101 \mathrm{MHz}$ respectively, using a Bruker Advance DRX 400 spectrometer. Solvent residual peaks were used as reference and calibrated as follows; $\mathrm{CDCl}_{3}$ : $7.26 \mathrm{ppm}$; MeOD- $d_{4}: 3.31 \mathrm{ppm}$; DMSO- $d_{6}: 2.50 \mathrm{ppm}$. Reactions were monitored by TLC (Merck Silica gel $\left.60 \mathrm{~F}_{254}\right)$ and analyzed under UV $(254 \mathrm{~nm})$. Reactions involving carbohydrates were followed by staining TLC plates with $\mathrm{H}_{2} \mathrm{SO}_{4}$ : $\mathrm{MeOH}: \mathrm{H}_{2} \mathrm{O}$ (3:45:45). Column chromatography was performed by manual flash chromatography (wet-packed silica, $0.04-0.063 \mathrm{~mm}$ ) or by automated column chromatography on a Grace Reveleris instrument using prepacked silica columns. Analytical high performance liquid chromatography (HPLC) was performed using a Waters $\mu$ Bondapak $\mathrm{C}_{18}$-column $(3.9 \times 300 \mathrm{~mm}, 125 \AA$ pore size, $10 \mu \mathrm{m}$ particle size $)$ connected to a Waters photodiode array detector 996. HPLC method A: 10-100\% $\mathrm{MeOH}$ in water 
(phosphoric acid $\mathrm{pH} 2.5$ ) over $5 \mathrm{~min}, 2 \mathrm{ml} / \mathrm{min}$. HPLC method $\mathrm{B}: 0-100 \% \mathrm{MeOH}$ in water (phosphoric acid pH 2.5) over $5 \mathrm{~min}$, then $100 \%$ water for $5 \mathrm{~min}, 2 \mathrm{ml} / \mathrm{min}$. Mass analyses (ESI) were recorded on a Bruker Daltonics Esquire 3000+ instrument and HRMS analyses were obtained on a Waters Xevo G2-S QTOF instrument.

6-((tert-Butoxycarbonyl)amino)hexanoic acid (3)

Following a published procedure, ${ }^{45} \mathrm{NaOH}(4.0 \mathrm{~g}, 0.1 \mathrm{~mol})$ was dissolved in water $(130 \mathrm{ml})$ and 1,4-dioxane $(260 \mathrm{ml})$ was added. $\omega$-Aminocapronic acid $(13.1 \mathrm{~g}, 99.9 \mathrm{mmol})$ was added, allowed to dissolve and the solution was cooled to $0{ }^{\circ} \mathrm{C}$. Di-tert-butyl dicarbonate $(24.0 \mathrm{~g}, 110$ mmol) was added in three portions, the reaction mixture was stirred at $0{ }^{\circ} \mathrm{C}$ for $30 \mathrm{~min}$ and then at r.t. for $16 \mathrm{~h}$. The 1,4-dioxane was removed by rotary evaporation and the crude was diluted with water $(400 \mathrm{ml})$ and washed with EtOAc $(2 \times 200 \mathrm{ml})$. The aqueous phase was acidified by addition of $1 \mathrm{M} \mathrm{HCl}$ (aq.) and extracted with EtOAc (3 x $300 \mathrm{ml})$. The organic phases from the second extraction were collected and dried over $\mathrm{MgSO}_{4}$. Removal of the solvents gave the expected product 3 as an oil that crystallizes to light pink crystals $(20.6 \mathrm{~g}, 89 \%$ yield $) . \mathrm{R}_{f}: 0.20$ $\left(2 \% \mathrm{MeOH}\right.$ in $\mathrm{CH}_{2} \mathrm{Cl}_{2}$ ). ${ }^{1} \mathrm{H} \mathrm{NMR}\left(400 \mathrm{MHz}, \mathrm{CDCl}_{3}\right) \delta 10.85$ (br s, $\left.1 \mathrm{H}\right), 5.97$ (br s, $0.3 \mathrm{H}$, CONH-), 4.63 (br s, 0.7H, -CONH-), 3.08 (br s, 2H), 2.32 (t, J=7.4 Hz, 2H), 1.62 (p, J= 7.5 $\mathrm{Hz}, 2 \mathrm{H}), 1.53-1.18(\mathrm{~m}, 13 \mathrm{H})$; ESI-MS $m / z[\mathrm{M}+\mathrm{Na}]^{+}: 254.2$.

4-Formylphenyl-6-((tert-butoxycarbonyl)amino)hexanoate (4)

$3(10.0 \mathrm{~g}, 43.2 \mathrm{mmol})$ was dissolved in dry $\mathrm{CH}_{2} \mathrm{Cl}_{2}(43 \mathrm{ml})$ in a two necked flask under argon. DCC (8.9 g, $43.2 \mathrm{mmol})$ and DMAP $(1.0 \mathrm{~g}, 8.2 \mathrm{mmol})$ were added, the reaction mixture was cooled to $0{ }^{\circ} \mathrm{C}$ and $p$-hydroxybenzaldehyde $(5.0 \mathrm{~g}, 41.2 \mathrm{mmol})$ was immediately added. The reaction was stirred at $0{ }^{\circ} \mathrm{C}$ for $30 \mathrm{~min}$ and then at r.t. for $21 \mathrm{~h}$. The white precipitate that formed was filtered off and washed twice with a small volume of $\mathrm{CH}_{2} \mathrm{Cl}_{2}$. The solvents were removed from the filtrate which gave an off-white solid that was redissolved in $\mathrm{CH}_{2} \mathrm{Cl}_{2}(200 \mathrm{ml})$, washed with $0.5 \mathrm{M} \mathrm{HCl}(50 \mathrm{ml})$, sat. $\mathrm{NaHCO}_{3}(50 \mathrm{ml})$ and brine $(50 \mathrm{ml})$. The organic phase was dried over $\mathrm{MgSO}_{4}$ and filtered. Removal of the solvents by rotary evaporation gave the crude as an off white solid. Purification by column chromatography on silica eluting with $2 \% \mathrm{MeOH}$ in $\mathrm{CH}_{2} \mathrm{Cl}_{2}$ gave 4 as a white solid (12.5 g, 86\% yield). $\mathrm{R}_{f}$ : $0.36\left(2 \% \mathrm{MeOH}\right.$ in $\left.\mathrm{CH}_{2} \mathrm{Cl}_{2}\right) ;{ }^{1} \mathrm{H}_{\mathrm{NMR}}$ $\left(400 \mathrm{MHz}, \mathrm{CDCl}_{3}\right) \delta 9.98(\mathrm{~s}, 1 \mathrm{H}), 7.95-7.86(\mathrm{~m}, 2 \mathrm{H}), 7.30-7.20(\mathrm{~m}, 2 \mathrm{H}), 4.57$ (br s, $\left.1 \mathrm{H}\right), 3.14$ $(\mathrm{q}, J=6.7 \mathrm{~Hz}, 2 \mathrm{H}), 2.59(\mathrm{t}, J=7.4 \mathrm{~Hz}, 2 \mathrm{H}), 1.77(\mathrm{p}, J=7.5 \mathrm{~Hz}, 2 \mathrm{H}), 1.61-1.49(\mathrm{~m}, 2 \mathrm{H}), 1.48$ $-1.38(\mathrm{~m}, 11 \mathrm{H}) ;{ }^{13} \mathrm{C} \mathrm{NMR}\left(101 \mathrm{MHz}, \mathrm{CDCl}_{3}\right) \delta 191.0,171.4,156.1,155.5,134.1,131.3,122.5$, 79.3, 40.5, 34.3, 29.9, 28.5, 26.3, 24.5; MS (ESI) $m / z:[\mathrm{M}+\mathrm{Na}]^{+}: 358.3 \mathrm{HRMS} m / z$ [M+Na] ${ }^{+}$ calculated for $\mathrm{C}_{18} \mathrm{H}_{25} \mathrm{NO}_{5} \mathrm{Na}: 358.1630$, found: 358.1627 .

4-(Hydroxymethyl)phenyl-6-((tert-butoxycarbonyl)amino)hexanoate (5)

$4(1.00 \mathrm{~g}, 2.98 \mathrm{mmol})$ was dissolved in trifluoroethanol $(6 \mathrm{ml})$ and the flask was cooled on ice. $\mathrm{NaBH}_{4}(107 \mathrm{mg}, 2.83 \mathrm{mmol})$ was added and the reaction was stirred on ice. Full consumption of 4 was observed after $1 \mathrm{~h}$ on TLC $\left(2 \% \mathrm{MeOH}\right.$ in $\left.\mathrm{CH}_{2} \mathrm{Cl}_{2}\right)$. The reaction was kept on ice and quenched by slow addition of sat. $\mathrm{NH}_{4} \mathrm{Cl}(7 \mathrm{ml})$ after $1 \mathrm{~h} 20 \mathrm{~min}$. The mixture was allowed to reach r.t. and stirred for $40 \mathrm{~min}$. Water $(5 \mathrm{ml})$ was added and the aqueous phase was extracted with EtOAc $(3 \times 30 \mathrm{ml})$. The organic phases were pooled, dried over $\mathrm{Na}_{2} \mathrm{SO}_{4}$ and filtered. Removal of the solvents gave a colorless oil, which was purified by flash column chromatography on silica eluting with $1 \% \mathrm{MeOH}$ in $\mathrm{CH}_{2} \mathrm{Cl}_{2}$ to obtain $\mathbf{5}$ as a white solid (900 mg, $90 \%$ yield). $\mathrm{R}_{f}: 0.32\left(2 \% \mathrm{MeOH}\right.$ in $\left.\mathrm{CH}_{2} \mathrm{Cl}_{2}\right) ;{ }^{1} \mathrm{H} \mathrm{NMR}\left(400 \mathrm{MHz}, \mathrm{CDCl}_{3}\right) \delta$ 7.37-7.29 (m, 2H), 7.06-6.99 (m, 2H), $4.62\left(\mathrm{~s}, 3 \mathrm{H},-\mathrm{CH}_{2}\right.$ - and-CONH-), $3.10(\mathrm{q}, J=6.6 \mathrm{~Hz}, 2 \mathrm{H}), 2.53(\mathrm{t}, J=$ $7.4 \mathrm{~Hz}, 2 \mathrm{H}), 2.49$ (br s, 1H), $1.74(\mathrm{p}, J=7.5 \mathrm{~Hz}, 2 \mathrm{H}), 1.56-1.46(\mathrm{~m}, 2 \mathrm{H}), 1.45-1.35(\mathrm{~m}, 11 \mathrm{H})$; ${ }^{13} \mathrm{C} \mathrm{NMR}\left(101 \mathrm{MHz}, \mathrm{CDCl}_{3}\right) \delta 172.2,156.1,150.0,138.7,128.0,121.6,79.2,64.6,40.4,34.3$, 
29.8, 28.5, 26.3, 24.6; MS (ESI) $m / z:[\mathrm{M}+\mathrm{Na}]^{+}:$360.2; HRMS $m / z[\mathrm{M}+\mathrm{Na}]^{+}$calculated for $\mathrm{C}_{18} \mathrm{H}_{27} \mathrm{NO}_{5} \mathrm{Na}: 360.1787$, found: 360.1786 .

\section{MalEsterOH (6)}

5 (400 mg, $1.19 \mathrm{mmol})$ was dissolved in dry $\mathrm{CH}_{2} \mathrm{Cl}_{2}(1.5 \mathrm{ml})$ and TFA (1.5 ml) was added. The reaction was stirred at r.t. for $20 \mathrm{~min}$. Full consumption of 5 was observed by TLC $(10 \% \mathrm{MeOH}$ in $\mathrm{CH}_{2} \mathrm{Cl}_{2}$ ). Solvents were removed and coevaporated four times with $\mathrm{CH}_{2} \mathrm{Cl}_{2}$. The resulting clear oil was redissolved in dry $\mathrm{CH}_{2} \mathrm{Cl}_{2}(2 \mathrm{ml})$ and basified (pH approx. 8) by addition of $\mathrm{N}$ methylmorpholine $(400 \mu \mathrm{l})$. 3-(Maleimidyl)propanoic acid $(220 \mathrm{mg}, 1.30 \mathrm{mmol})$ was added, the reaction was cooled on ice and DCC (268 mg, $1.30 \mathrm{mmol})$ was added. The ice bath was removed and the reaction was stirred at r.t. for $17 \mathrm{~h}$. The white precipitate that had formed was filtered off and the filtrate was concentrated. The yellow oil that resulted was redissolved in $\mathrm{CH}_{2} \mathrm{Cl}_{2}(20 \mathrm{ml})$, washed with $0.5 \mathrm{M} \mathrm{HCl}(5 \mathrm{ml})$ and dried over $\mathrm{MgSO}_{4}$ and filtered. Removal of the solvents gave a white solid, which was purified by flash column chromatography on silica eluting with $25 \%$ cyclohexane in EtOAc to obtain $\mathbf{6}$ as a white solid (236 mg, $51 \%$ yield). $\mathrm{R}_{f}$ : $0.52\left(10 \% \mathrm{MeOH}\right.$ in $\left.\mathrm{CH}_{2} \mathrm{Cl}_{2}\right) ;{ }^{1} \mathrm{H}$ NMR $\left(400 \mathrm{MHz}, \mathrm{CDCl}_{3}\right) \delta$ 7.41-7.34 (m, 2H), 7.09-7.02 (m, $2 \mathrm{H}), 6.68(\mathrm{~s}, 2 \mathrm{H}), 5.74(\mathrm{br} \mathrm{s}, 1 \mathrm{H}), 4.67(\mathrm{~s}, 2 \mathrm{H}), 3.81(\mathrm{t}, J=7.2 \mathrm{~Hz}, 2 \mathrm{H}), 3.28-3.19(\mathrm{~m}, 2 \mathrm{H}), 2.55$ $(\mathrm{t}, J=7.3 \mathrm{~Hz}, 2 \mathrm{H}), 2.48(\mathrm{t}, J=7.2 \mathrm{~Hz}, 2 \mathrm{H}), 1.86(\mathrm{br} \mathrm{s}, 1 \mathrm{H}), 1.75(\mathrm{p}, J=7.4 \mathrm{~Hz}, 2 \mathrm{H}), 1.58-$ $1.48(\mathrm{~m}, 2 \mathrm{H}), 1.46-1.36(\mathrm{~m}, 2 \mathrm{H}) ;{ }^{13} \mathrm{C} \mathrm{NMR}\left(101 \mathrm{MHz}, \mathrm{CDCl}_{3}\right) \delta 172.3,170.7,169.6,150.2$, 138.7, 134.3, 128.2, 121.8, 64.8, 39.4, 34.9, 34.4, 34.2, 29.2, 26.4, 24.5; MS (ESI) $m / z$ : $[\mathrm{M}+\mathrm{Na}]^{+}:$411.3; HRMS $m / z[\mathrm{M}+\mathrm{H}]^{+}$calculated for $\mathrm{C}_{20} \mathrm{H}_{25} \mathrm{~N}_{2} \mathrm{O}_{6}: 389.1713$, found: 389.1714 .

\section{MalEsterPNP (7)}

6 (178 $\mathrm{mg}, 0.46 \mathrm{mmol})$ and bis ( $p$-nitrophenyl)carbonate $(210 \mathrm{mg}, 0.69 \mathrm{mmol})$ were added to a dry flask filled with argon which was capped, evacuated and refilled with argon (repeated 3 times). Dry $\mathrm{CH}_{2} \mathrm{Cl}_{2}$ (4.6 ml) was added followed by diisoproylethylamine ( $\left.245 \mu 1,1.38 \mathrm{mmol}\right)$. The yellow reaction mixture was stirred at r.t. for $4 \mathrm{~h}$ in the dark. Full consumption of 6 was observed on TLC $\left(2 \% \mathrm{MeOH}\right.$ in $\left.\mathrm{CH}_{2} \mathrm{Cl}_{2}\right)$. The reaction mixture was diluted with $\mathrm{CH}_{2} \mathrm{Cl}_{2}(25$ $\mathrm{ml})$ and washed with aq. citric acid $(10 \% \mathrm{w} / \mathrm{v})$. The organic phase was dried over $\mathrm{Na}_{2} \mathrm{SO}_{4}$ and filtered. Removal of the solvents gave a yellow oil. DEE $(25 \mathrm{ml})$ was added and brief sonication resulted in a white precipitate. The precipitate was filtered off, washed with DEE repeatedly, collected and redissolved in a minimum of $\mathrm{CH}_{2} \mathrm{Cl}_{2}$. The solution was added dropwise to stirred DEE $(25 \mathrm{ml})$. The white precipitate that formed was collected by filtration and dried to give 7 as a white solid (178 mg, 70\% yield). $\mathrm{R}_{f}: 0.28\left(2 \% \mathrm{MeOH}\right.$ in $\left.\mathrm{CH}_{2} \mathrm{Cl}_{2}\right) ;{ }^{1} \mathrm{H} \mathrm{NMR}(400 \mathrm{MHz}$, $\left.\mathrm{CDCl}_{3}\right) \delta 8.31-8.23(\mathrm{~m}, 2 \mathrm{H}), 7.50-7.43(\mathrm{~m}, 2 \mathrm{H}), 7.41-7.35(\mathrm{~m}, 2 \mathrm{H}), 7.16-7.09(\mathrm{~m}, 2 \mathrm{H}), 6.70(\mathrm{~s}$, $2 \mathrm{H}), 5.64(\mathrm{br} \mathrm{s}, 1 \mathrm{H}), 5.28(\mathrm{~s}, 2 \mathrm{H}), 3.84(\mathrm{t}, J=7.2 \mathrm{~Hz}, 1 \mathrm{H}), 3.31-3.20(\mathrm{~m}, 2 \mathrm{H}), 2.58(\mathrm{t}, J=7.4$ $\mathrm{Hz}, 1 \mathrm{H}), 2.51(\mathrm{t}, J=7.1 \mathrm{~Hz}, 1 \mathrm{H}), 1.82-1.72(\mathrm{~m}, 2 \mathrm{H}), 1.58-1.50(\mathrm{~m}, 2 \mathrm{H}), 1.49-1.38(\mathrm{~m}, 2 \mathrm{H})$; ${ }^{13} \mathrm{C}$ NMR $\left(101 \mathrm{MHz}, \mathrm{CDCl}_{3}\right) \delta 172.0,170.7,169.6,155.6,152.6,151.3,145.6,134.4,131.9$, $130.2,125.5,122.2,121.9,70.4,39.4,34.9,34.4,34.3,29.3,26.4,24.5$; MS (ESI) $m / z:[\mathrm{M}+\mathrm{H}]^{+}$: 554.2 and $[\mathrm{M}+\mathrm{Na}]^{+}: 576.2$; HRMS $m / z[\mathrm{M}+\mathrm{H}]^{+}$calculated for $\mathrm{C}_{27} \mathrm{H}_{28} \mathrm{~N}_{3} \mathrm{O}_{10}: 554.1775$, found: 554.1776 .

\section{MalEsterDox (1)}

7 (132 mg, $0.24 \mathrm{mmol})$ was dissolved in dry DMF $(2.2 \mathrm{ml})$ and the solution was added to Doxorubicin hydrochloride ( $128 \mathrm{mg}, 0.22 \mathrm{mmol})$. Et ${ }_{3} \mathrm{~N}(61 \mu \mathrm{l}, 0.44 \mathrm{mmol})$ was added and the dark red reaction mixture was stirred under argon. After $22 \mathrm{~h}$, the reaction mixture was added dropwise to stirred DEE $(75 \mathrm{ml})$ resulting in a red precipitate which was collected by filtration and further purified by flash column chromatography eluting with 2-5\% $\mathrm{MeOH}$ in $\mathrm{CH}_{2} \mathrm{Cl}_{2} .1$ (124 mg, 59\% yield) was isolated as a red foam. $\mathrm{R}_{f}: 0.29\left(5 \% \mathrm{MeOH}\right.$ in $\left.\mathrm{CH}_{2} \mathrm{Cl}_{2}\right)$; ${ }^{1} \mathrm{H} \mathrm{NMR}$ $\left(400 \mathrm{MHz}, \mathrm{CDCl}_{3}\right) \delta 13.96(\mathrm{~s}, 1 \mathrm{H}), 13.23(\mathrm{~s}, 1 \mathrm{H}), 8.02(\mathrm{dd}, J=7.7,1.1 \mathrm{~Hz}, 1 \mathrm{H}), 7.82-7.73$ 
(m, 1H), $7.39(\mathrm{dd}, J=8.6,1.1 \mathrm{~Hz}, 1 \mathrm{H}), 7.31(\mathrm{~d}, J=8.0 \mathrm{~Hz}, 2 \mathrm{H}), 7.01(\mathrm{~d}, J=8.0 \mathrm{~Hz}, 2 \mathrm{H}), 6.68$ (s, 2H), 5.73 (s, 1H), 5.49 (d, $J=3.8 \mathrm{~Hz}, 1 \mathrm{H}), 5.28(\mathrm{br} \mathrm{s}, 1 \mathrm{H}), 5.22(\mathrm{~d}, J=8.6 \mathrm{~Hz}, 1 \mathrm{H}), 5.08-$ $4.91(\mathrm{~m}, 2 \mathrm{H}), 4.75(\mathrm{dd}, J=5.0,1.4 \mathrm{~Hz}, 2 \mathrm{H}), 4.57(\mathrm{~s}, 1 \mathrm{H}), 4.18-4.08(\mathrm{~m}, 1 \mathrm{H}), 4.07(\mathrm{~s}, 3 \mathrm{H})$, $3.85(\mathrm{br} \mathrm{s}, 1 \mathrm{H}), 3.81(\mathrm{t}, J=7.2 \mathrm{~Hz}, 2 \mathrm{H}), 3.66(\mathrm{~d}, J=7.2 \mathrm{~Hz}, 1 \mathrm{H}), 3.32-3.16(\mathrm{~m}, 3 \mathrm{H}), 3.08-$ $2.94(\mathrm{~m}, 2 \mathrm{H}), 2.53(\mathrm{t}, J=7.3 \mathrm{~Hz}, 2 \mathrm{H}), 2.48(\mathrm{t}, J=7.2 \mathrm{~Hz}, 2 \mathrm{H}), 2.39-2.27(\mathrm{~m}, 1 \mathrm{H}), 2.25-2.10$ ( $\mathrm{m}, 2 \mathrm{H}), 1.91-1.68(\mathrm{~m}, 4 \mathrm{H}), 1.52(\mathrm{p}, J=7.1 \mathrm{~Hz}, 2 \mathrm{H}), 1.46-1.33(\mathrm{~m}, 2 \mathrm{H}), 1.28(\mathrm{~d}, J=6.5 \mathrm{~Hz}$, $3 \mathrm{H}) ;{ }^{13} \mathrm{C}$ NMR $\left(101 \mathrm{MHz}, \mathrm{CDCl}_{3}\right) \delta 214.0,187.2,186.8,172.2,170.7,169.7,161.2,156.3$, 155.8, 155.6, 150.6, 135.9, 135.6, 134.3, 134.1, 133.7, 129.5, 121.8, 121.0, 120.0, 118.6, 111.7, 111.6, 110.1, 100.8, 76.8, 69.7, 69.6, 67.5, 66.2, 65.7, 56.8, 47.2, 39.4, 35.8, 34.9, 34.4, 34.2, 34.1, 30.3, 29.2, 26.4, 24.5, 17.0; MS (ESI) $m / z:[\mathrm{M}+\mathrm{Na}]^{+}: 980.3 ; \quad \mathrm{HRMS} \mathrm{m} / z[\mathrm{M}+\mathrm{H}]^{+}$ calculated for $\mathrm{C}_{48} \mathrm{H}_{52} \mathrm{~N}_{3} \mathrm{O}_{18}$ : 958.3246 , found: 958.3235 .

\section{FmocLys(Alloc)PABOH (9)}

Following a published procedure, ${ }^{32}$ FmocLys(Alloc)OH $(1.44 \mathrm{~g}, 3.18 \mathrm{mmol}$ ) was dissolved in dry THF $(20 \mathrm{ml})$ under argon in a two-necked flask equipped with an addition funnel. The solution was cooled to $-40{ }^{\circ} \mathrm{C}$ and $\mathrm{N}$-methylmorpholine $(0.39 \mathrm{ml}, 3.54 \mathrm{mmol})$ and isobutyl chloroformate $(0.45 \mathrm{ml}, 3.47 \mathrm{mmol})$ were added. The turbid mixture was stirred at $-40{ }^{\circ} \mathrm{C}$ for 3 $\mathrm{h}$ after which a solution of $p$-aminobenzylalcohol $(470 \mathrm{mg}, 3.82 \mathrm{mmol})$ and $\mathrm{N}$ methylmorpholine $(0.42 \mathrm{ml}, 3.82 \mathrm{mmol})$ in dry THF $(6 \mathrm{ml})$ was added dropwise over $10 \mathrm{~min}$. The reaction mixture was stirred at $-40{ }^{\circ} \mathrm{C}$ for $2 \mathrm{~h}$ and then at room temperatrure for $1 \mathrm{~h}$. The solvents were removed and the yellow residue was taken up in $\mathrm{CH}_{2} \mathrm{Cl}_{2}(250 \mathrm{ml})$. The organic phase was washed with $0.5 \mathrm{M} \mathrm{NaHCO}_{3}$ solution $(100 \mathrm{ml}), 0.5 \mathrm{M} \mathrm{NaHSO}_{4}$ solution $(100 \mathrm{ml})$ and brine $(100 \mathrm{ml})$. The organic solvents were removed under reduced pressure and the yellow residue was purified by flash column chromatography on silica (2-10\% methanol in $\mathrm{CH}_{2} \mathrm{Cl}_{2}$ ) to provide 9 as a white solid $\left(1.28 \mathrm{~g}, 72 \%\right.$ yield). ${ }^{1} \mathrm{H}$ NMR $\left(400 \mathrm{MHz}, \mathrm{dmso}-d_{6}\right) \delta 9.96(\mathrm{~s}, 1 \mathrm{H})$, $7.89(\mathrm{~d}, J=7.5 \mathrm{~Hz}, 2 \mathrm{H}), 7.74(\mathrm{dd}, J=7.5,4.9 \mathrm{~Hz}, 2 \mathrm{H}), 7.62(\mathrm{~d}, J=7.9 \mathrm{~Hz}, 1 \mathrm{H}), 7.55(\mathrm{~d}, J=$ $8.4 \mathrm{~Hz}, 2 \mathrm{H}), 7.41(\mathrm{t}, J=7.3 \mathrm{~Hz}, 2 \mathrm{H}), 7.37-7.29(\mathrm{~m}, 2 \mathrm{H}), 7.24(\mathrm{~d}, J=8.3 \mathrm{~Hz}, 2 \mathrm{H}), 7.19(\mathrm{t}, J=$ $5.8 \mathrm{~Hz}, 1 \mathrm{H}), 5.89$ (ddt, $J=17.2,10.5,5.3 \mathrm{~Hz}, 1 \mathrm{H}), 5.30-5.20(\mathrm{~m}, 1 \mathrm{H}), 5.18-5.12(\mathrm{~m}, 1 \mathrm{H}), 5.10$ $(\mathrm{t}, J=5.7 \mathrm{~Hz}, 1 \mathrm{H}) 4.52-4.39(\mathrm{~m}, 4 \mathrm{H}), 4.34-4.06(\mathrm{~m}, 4 \mathrm{H}), 3.07-2.91(\mathrm{~m}, 2 \mathrm{H}), 1.75-1.56(\mathrm{~m}$, 2H), $1.51-1.21(\mathrm{~m}, 4 \mathrm{H}) .{ }^{13} \mathrm{C}$ NMR (101 MHz, DMSO- $\left.d_{6}\right) \delta 171.0,156.1,155.9,143.9,143.8$, 140.7, 137.5, 137.4, 133.8, 127.6, 127.0, 126.9, 125.3, 120.1, 118.9, 116.8, 65.6, 64.1, 62.6, 55.4, 46.7, 31.6, 29.1, 22.9. HRMS $m / z[\mathrm{M}+\mathrm{H}]^{+}$calculated for $\mathrm{C}_{32} \mathrm{H}_{36} \mathrm{~N}_{3} \mathrm{O}_{6}$ : 558.2604, found: 558.2606.

\section{Tripep (10)}

Compound 9 (560 mg, $1.00 \mathrm{mmol})$ was dissolved in a premade mixture of 1,4dioxane:MeOH:2M NaOH(aq.) (14:5:1, $20 \mathrm{ml}$ ). ${ }^{46}$ After 30 min (TLC, $\mathrm{CH}_{2} \mathrm{Cl}_{2}: \mathrm{MeOH} 90: 10$ ), the solution was neutralized by addition of acetic acid. The solvents were removed by evaporation and coevaporated with 1,4-dioxane $(2 \times 20 \mathrm{ml})$. The oily solid residue was washed with DEE (3 x $10 \mathrm{ml})$ and then with $\mathrm{CH}_{2} \mathrm{Cl}_{2}(10 \times 10 \mathrm{ml})$. The $\mathrm{CH}_{2} \mathrm{Cl}_{2}$ fractions were collected and the solvent was removed to yield the free amine as a pale yellow oil (326 mg) which was used in the next step without further purification.

A solution of DMTMMBF 4 (365 mg, $1.11 \mathrm{mmol})$, FmocPheOH $(390 \mathrm{mg}, 1.01 \mathrm{mmol})$ and $\mathrm{N}$ methyl morpholine $(121 \mu \mathrm{l}, 1.10 \mathrm{mmol})$ in $\mathrm{CH}_{3} \mathrm{CN}(5 \mathrm{ml})$ was stirred for $10 \mathrm{~min}$ and then added to a solution of the crude form the previous step $\left(326 \mathrm{mg}\right.$ ) in $\mathrm{CH}_{3} \mathrm{CN}(5 \mathrm{ml})$. The reaction mixture was stirred at r.t for $19 \mathrm{~h}$ (TLC, $\mathrm{CH}_{2} \mathrm{Cl}_{2}: \mathrm{MeOH}$ 90:10). The solvents were removed by evaporation and $\mathrm{CH}_{2} \mathrm{Cl}_{2}(100 \mathrm{ml})$ was added and the organic phase was washed with water (25 $\mathrm{ml}), 0.5 \mathrm{M} \mathrm{NaHCO}_{3}(25 \mathrm{ml}), 0.5 \mathrm{M} \mathrm{NaHSO}_{4}(3 \times 25 \mathrm{ml})$ and water $(50 \mathrm{ml})$. The solvents were removed from the organic phase to give an off-white solid $(665 \mathrm{mg})$ which was used in the next step without further purification. 
A premade mixture of 1,4-dioxane:MeOH:2M NaOH(aq.) (14:5:1, $20 \mathrm{ml}$ ) was added to the crude from the previous step and the reaction mixture was stirred at r.t. for 50 min (TLC, $\mathrm{CH}_{2} \mathrm{Cl}_{2}: \mathrm{MeOH}$ 90:10). The reaction was neutralized by addition of acetic acid. The solvents were removed by evaporation and coevaporated with 1,4-dioxane $(20 \mathrm{ml})$. The resulting white residue was washed with DEE $(3 \times 5 \mathrm{ml})$ and then with $\mathrm{CH}_{2} \mathrm{Cl}_{2}(10 \times 20 \mathrm{ml})$. The white precipitate formed in the DEE phase was collected by filtration, dissolved in $\mathrm{CH}_{2} \mathrm{Cl}_{2}$ and pooled with the other $\mathrm{CH}_{2} \mathrm{Cl}_{2}$ fractions. The $\mathrm{CH}_{2} \mathrm{Cl}_{2}$ fractions were collected and the solvent was removed to yield the free amine as an off white solid $(463 \mathrm{mg})$ which was used in the next step without further purification.

A solution of DMTMMBF 4 (360 mg, $1.10 \mathrm{mmol}$ ), Boc-D-AlaOH (190 mg, $1.00 \mathrm{mmol})$ and $\mathrm{N}$ methyl morpholine $(121 \mu \mathrm{l}, 1.10 \mathrm{mmol})$ in $\mathrm{CH}_{3} \mathrm{CN}(5 \mathrm{ml})$ was stirred for $10 \mathrm{~min}$ and then added to a solution of the crude from the previous step $(463 \mathrm{mg})$ in $\mathrm{CH}_{3} \mathrm{CN}(6 \mathrm{ml})$. The reaction mixture was stirred at r.t for $14 \mathrm{~h}$ ( TLC, $\mathrm{CH}_{2} \mathrm{Cl}_{2}: \mathrm{MeOH}$ 90:10). The solvents were removed by evaporation and $\mathrm{CH}_{2} \mathrm{Cl}_{2}(70 \mathrm{ml})$ was added and the organic phase was washed with water (40 $\mathrm{ml}), 0.5 \mathrm{M} \mathrm{NaHSO}_{4}(2 \times 20 \mathrm{ml}), 0.5 \mathrm{M} \mathrm{NaHCO}_{3}(3 \times 20 \mathrm{ml})$ and water $(20 \mathrm{ml})$. The solvents were removed from the organic phase to give an off-white solid, which was purified by flash column chromatography on silica eluting with 2-5\% methanol in $\mathrm{CH}_{2} \mathrm{Cl}_{2}$. The product was dryloaded on to the column after being dissolved in $10 \%$ methanol in $\mathrm{CH}_{2} \mathrm{Cl}_{2}$ and dried on to silica. Compound 10 was isolated as a white solid (309 mg, $47 \%$ over 4 steps). ${ }^{1} \mathrm{H}$ NMR (400 $\left.\mathrm{MHz}, \mathrm{MeOD}-d_{4}\right) \delta 7.61(\mathrm{~d}, J=8.3 \mathrm{~Hz}, 2 \mathrm{H}), 7.30(\mathrm{~d}, J=8.5 \mathrm{~Hz}, 2 \mathrm{H}), 7.28-7.09(\mathrm{~m}, 5 \mathrm{H}), 5.91$ (ddt, $J=16.3,10.7,5.5 \mathrm{~Hz}, 1 \mathrm{H}), 5.28(\mathrm{dd}, J=17.1,1.7 \mathrm{~Hz}, 1 \mathrm{H}), 5.16(\mathrm{~d}, J=10.5 \mathrm{~Hz}, 1 \mathrm{H}), 4.60$ $(\mathrm{dd}, J=9.8,4.5 \mathrm{~Hz}, 1 \mathrm{H}), 4.56(\mathrm{~s}, 2 \mathrm{H}), 4.50(\mathrm{~d}, J=5.0 \mathrm{~Hz}, 2 \mathrm{H}), 4.43(\mathrm{dd}, J=9.6,4.9 \mathrm{~Hz}, 1 \mathrm{H})$, $4.00(\mathrm{q}, J=7.1 \mathrm{~Hz}, 1 \mathrm{H}), 3.30-3.23(\mathrm{~m}, 1 \mathrm{H}), 3.11(\mathrm{t}, J=6.7 \mathrm{~Hz}, 2 \mathrm{H}), 2.95(\mathrm{dd}, J=14.2,9.8 \mathrm{~Hz}$, $1 \mathrm{H}), 2.02-1.78(\mathrm{~m}, 2 \mathrm{H}), 1.59-1.40(\mathrm{~m}, 4 \mathrm{H}) 1.33(\mathrm{~s}, 9 \mathrm{H}), 1.13(\mathrm{~d}, J=7.1 \mathrm{~Hz}, 3 \mathrm{H}) .{ }^{13} \mathrm{C} \mathrm{NMR}$ $\left(101 \mathrm{MHz}, \mathrm{MeOD}-d_{4}\right) \delta 176.9,173.6,172.2,158.8,157.9,138.8,138.5,138.4,134.5,130.2$, $129.5,128.5,127.8,121.4,117.4,80.7,66.3,64.8,56.4,55.7,51.8,41.5,37.9,32.3,30.5,28.7$, 24.5, 17.7. HRMS $m / z[\mathrm{M}+\mathrm{H}]^{+}$calculated for $\mathrm{C}_{34} \mathrm{H}_{48} \mathrm{~N}_{5} \mathrm{O}_{8}: 654.3503$, found: 654.3496.

\section{MaltriPep (11)}

10 (150 mg, $0.23 \mathrm{mmol})$ was suspended in dry $\mathrm{CH}_{2} \mathrm{Cl}_{2}(1 \mathrm{ml})$ under argon, TFA $(0.8 \mathrm{ml})$ was added and the solution was stirred for $15 \mathrm{~min}$. Full consumption of $\mathbf{1 0}$ was confirmed by TLC (10\% methanol in $\left.\mathrm{CH}_{2} \mathrm{Cl}_{2}\right)$. The solvents were removed and coevaporated with $\mathrm{CH}_{2} \mathrm{Cl}_{2}(3 \times 1$ $\mathrm{ml})$. The resulting residue was taken up in $\mathrm{CH}_{3} \mathrm{CN}(3.5 \mathrm{ml})$ and neutralized by addition of NMM (150 $\mu \mathrm{l})$. DMTMMBF 4 ( $82 \mathrm{mg}, 0.25 \mathrm{mmol})$, 3-(maleimidyl)propanoic acid (46 mg, $0.27 \mathrm{mmol}$ ) and NMM $(27 \mu \mathrm{l}, 0.25 \mathrm{mmol})$ were stirred in $\mathrm{CH}_{3} \mathrm{CN}(1.5 \mathrm{ml})$ at r.t. until all material dissolved ( $\sim 5 \mathrm{~min})$. The solution of deprotected $\mathbf{1 0}$ was then added and the reaction mixture was stirred at r.t. for $22 \mathrm{~h}$. The formed precipitate was filtered off and washed with ice cold $\mathrm{CH}_{3} \mathrm{CN}$ and DEE. The filtrate was collected, diluted in $\mathrm{CH}_{2} \mathrm{Cl}_{2}(100 \mathrm{ml})$ and washed with $0.5 \mathrm{M} \mathrm{NaHSO}_{4}$ $(30 \mathrm{ml})$ and water $(30 \mathrm{ml})$. The organic phases were dried over $\mathrm{MgSO}_{4}$ and the solvents were then removed to give a white solid which was pooled with the precipitated material. The crude was purified by flash column chromatography on silica eluting with $5 \%$ methanol in $\mathrm{CH}_{2} \mathrm{Cl}_{2}$. The crude product was dryloaded on to the column after being dissolved in methanol and dried on to silica. The expected product 11 was isolated as a white solid (72 $\mathrm{mg}, 43 \%$ over 2 steps). ${ }^{1} \mathrm{H}$ NMR (400 MHz, MeOD-d $) \delta 7.60(\operatorname{app~d}, 2 \mathrm{H}), 7.29(\operatorname{app} \mathrm{d}, 2 \mathrm{H}), 7.28-7.14(\mathrm{~m}, 5 \mathrm{H}), 6.76$ $(\mathrm{s}, 2 \mathrm{H}) 5.91(\mathrm{ddt}, J=16.3,10.6,5.4 \mathrm{~Hz}, 1 \mathrm{H}), 5.28(\mathrm{dd}, J=17.2,1.8 \mathrm{~Hz}, 1 \mathrm{H}), 5.20-5.12(\mathrm{~m}$, $1 \mathrm{H}), 4.62-4.52(\mathrm{~m}, 3 \mathrm{H}), 4.50(\mathrm{dt}, J=5.6,1.6 \mathrm{~Hz}, 2 \mathrm{H}), 4.40(\mathrm{dd}, J=9.6,5.0 \mathrm{~Hz}, 1 \mathrm{H}), 4.14(\mathrm{q}$, $J=7.1 \mathrm{~Hz}, 1 \mathrm{H}), 3.73-3.57(\mathrm{~m}, 2 \mathrm{H}), 3.30-3.25(\mathrm{~m}, 1 \mathrm{H}$, partly overlapping with solvent peak), $3.13(\mathrm{t}, J=6.7 \mathrm{~Hz}, 2 \mathrm{H}), 2.95(\mathrm{dd}, J=14.2,10.0 \mathrm{~Hz}, 1 \mathrm{H}), 2.47-2.27(\mathrm{~m}, 2 \mathrm{H}), 2.00-1.84(\mathrm{~m}$, $2 \mathrm{H}), 1.62-1.36(\mathrm{~m}, 4 \mathrm{H}), 1.14(\mathrm{~d}, J=7.1 \mathrm{~Hz}, 3 \mathrm{H}) .{ }^{13} \mathrm{C}$ NMR $\left(101 \mathrm{MHz}, \mathrm{MeOD}-d_{4}\right) \delta 176.2$, $173.7,173.2$, 172.4, 172.1, 158.8, 138.8, 138.5, 135.4, 134.6, 130.2, 129.5, 128.5, 127.8, 121.4, 
117.4, 112.9, 66.3, 64.8, 56.7, 55.8, 51.1, 41.5, 37.8, 35.2, 35.1, 32.3, 30.5, 24.5, 17.1. MS (ESI) $m / z:[\mathrm{M}+\mathrm{H}]^{+}: 705.4$ and $[\mathrm{M}+\mathrm{Na}]^{+}:$727.4; HRMS $\mathrm{m} / z[\mathrm{M}+\mathrm{H}]^{+}$calculated for $\mathrm{C}_{36} \mathrm{H}_{45} \mathrm{~N}_{6} \mathrm{O}_{9}$ : 705.3248, found: 705.3253 .

\section{MaltriPepOPNP (12)}

11 (65 mg, $0.09 \mathrm{mmol})$ and bis (p-nitrophenyl)carbonate $(82 \mathrm{mg}, 0.27 \mathrm{mmol})$ were dissolved in dry DMF $(1.5 \mathrm{ml})$ under argon. The flask was capped, evacuated and refilled with argon several short turns before DIPEA $(47 \mu \mathrm{l}, 0.27 \mathrm{mmol})$ was added by syringe. The reaction mixture was stirred at r.t. for $23 \mathrm{~h}$ at which time a second portion of bis( $p$-nitrophenyl)carbonate $(55 \mathrm{mg}$, $0.18 \mathrm{mmol}$ ) was added. The reaction was stirred for an additional $23 \mathrm{~h}$ after which all 11 was consumed as verified by TLC (5\% methanol in $\left.\mathrm{CH}_{2} \mathrm{Cl}_{2}\right)$. The reaction mixture was diluted in $\mathrm{CH}_{2} \mathrm{Cl}_{2}$ (40 ml), washed with citric acid solution (10 wt $\left.\%, 2 \times 15 \mathrm{ml}\right)$ and dried over $\mathrm{MgSO}_{4}$. The solvents were removed resulting in a yellow oil, which was dissolved in a small amount of $\mathrm{CH}_{2} \mathrm{Cl}_{2}$ and added dropwise to DEE (40 ml) while stirring. The product precipitated as a white solid $\left(60 \mathrm{mg}\right.$ ) containing 15\% p-nitrophenol (estimated from ${ }^{1} \mathrm{H}-\mathrm{NMR}$ integrals). The identity of the expected product was confirmed by ${ }^{1} \mathrm{H}-\mathrm{NMR}$, ESI-MS and HRMS and the material was used without further purification in the following step. ${ }^{1} \mathrm{H}$ NMR $\left(400 \mathrm{MHz}, \mathrm{MeOD}-d_{4}\right) \delta 8.31$ (app d, 2H), $7.69(\mathrm{~d}, J=8.6 \mathrm{~Hz}, 2 \mathrm{H}), 7.46(\operatorname{app~d}, 2 \mathrm{H}), 7.41(\mathrm{~d}, J=8.6 \mathrm{~Hz}, 2 \mathrm{H}), 7.31-7.23(\mathrm{~m}$, $4 \mathrm{H}), 7.23-7.16(\mathrm{~m}, 1 \mathrm{H}), 6.74(\mathrm{~s}, 2 \mathrm{H}), 5.97-5.84(\mathrm{~m}, 1 \mathrm{H}), 5.33-5.23(\mathrm{~m}, 3 \mathrm{H}), 5.16(\mathrm{~d}, J=10.5$ $\mathrm{Hz}, 1 \mathrm{H}), 4.56(\mathrm{dd}, J=10.0,4.4 \mathrm{~Hz}, 1 \mathrm{H}), 4.53-4.46(\mathrm{~m}, 2 \mathrm{H}), 4.41(\mathrm{dd}, J=9.6,5.0 \mathrm{~Hz}, 1 \mathrm{H})$, $4.14(\mathrm{q}, J=7.1 \mathrm{~Hz}, 1 \mathrm{H}), 3.73-3.44(\mathrm{~m}, 3 \mathrm{H}), 3.14(\mathrm{t}, J=6.7 \mathrm{~Hz}, 2 \mathrm{H}), 2.95(\mathrm{dd}, J=14.2,10.1$ $\mathrm{Hz}, 1 \mathrm{H}), 2.46-2.25(\mathrm{~m}, 2 \mathrm{H}), 2.08-1.81(\mathrm{~m}, 1 \mathrm{H}), 1.63-1.37(\mathrm{~m}, 4 \mathrm{H}), 1.15(\mathrm{~d}, J=7.1 \mathrm{~Hz}, 3 \mathrm{H})$. MS (ESI) $m / z:[\mathrm{M}+\mathrm{Na}]^{+}:$892.3; HRMS $m / z$ : $[\mathrm{M}+\mathrm{H}]^{+}$calculated for $\mathrm{C}_{43} \mathrm{H}_{48} \mathrm{~N}_{7} \mathrm{O}_{13}: 870.3310$, found: 870.3318 .

\section{MaltriPepDox (13)}

$12(53 \mathrm{mg}, 0.061 \mathrm{mmol})$ was dissolved in dry DMF $(1.7 \mathrm{ml})$ and the hydrochloride salt of doxorubicin ( $35 \mathrm{mg}, 0.061 \mathrm{mmol}$ ) was added followed by $\mathrm{Et}_{3} \mathrm{~N}(18 \mu \mathrm{l}, 0.12 \mathrm{mmol})$. The reaction mixture was stirred at r.t. and followed by TLC (5\% methanol in $\mathrm{CH}_{2} \mathrm{Cl}_{2}$ ). After $24 \mathrm{~h}$, the reaction mixture was added dropwise to DEE $(35 \mathrm{ml})$ under stirring which resulted in a red precipitate. The precipitate was collected by filtration and isolated by washing the filter paper with a solution of 5\% methanol in $\mathrm{CH}_{2} \mathrm{Cl}_{2}$. The solvents were removed to give a red solid, which was purified by flash column chromatography on silica eluting with $5 \%$ methanol in $\mathrm{CH}_{2} \mathrm{Cl}_{2}$. The product was dryloaded on to the column after being dissolved in methanol: $\mathrm{CH}_{2} \mathrm{Cl}_{2}$ mixture and dried on to silica. The expected product 13 was isolated as a red solid $(59 \mathrm{mg}$, 75\%). HPLC method A. MS (ESI) $m / z:[\mathrm{M}+\mathrm{Na}]^{+}: 1296.5$; HRMS $m / z[\mathrm{M}+\mathrm{Na}]^{+}$calculated for $\mathrm{C}_{64} \mathrm{H}_{71} \mathrm{~N}_{7} \mathrm{O}_{21} \mathrm{Na}$ : 1296.4601, found: 1296.4608 . Characteristic peaks of maleimidyl (6.96 ppm, $\mathrm{s}, 2 \mathrm{H}$ ), Vinyl proton from Alloc protecting group $(5.86 \mathrm{ppm}, \mathrm{m}, 1 \mathrm{H})$, methoxy methyl of doxorubicin (3.97 ppm, s, 3H), Alaninyl methyl (1.12 ppm, d, 3H) and doxorubicin glycon methyl $(0.91 \mathrm{ppm}, \mathrm{d}, 3 \mathrm{H})$ with matching integrals found on ${ }^{1} \mathrm{H}-\mathrm{NMR}$ (DMSO-d $\left.\mathrm{d}_{6}\right)$ (see SI).

\section{$N$-Acetamido- $N$-furfuryl-XGO (15)}

A solution of $\mathrm{XGO}^{41}(1.015 \mathrm{~g}, 8.3 \mathrm{mmol}$ based on the octasaccharide) in furfurylamine $(4 \mathrm{~mL})$ was stirred for $72 \mathrm{~h}$ at $25^{\circ} \mathrm{C}$. The solution was poured into ethyl acetate $(25 \mathrm{~mL})$, cooled to $0^{\circ} \mathrm{C}$ and centrifuged for $20 \mathrm{~min}$ at $6000 \mathrm{rpm}$. The solid was washed with ethyl acetate and centrifuged again. The crude solid of glycosylamine was then dissolved in methanol $(15 \mathrm{~mL})$ and acetic anhydride $(7 \mathrm{~mL})$ was slowly added at $0^{\circ} \mathrm{C}$ to the solution. The reaction mixture was then allowed to warm up to room temperature and stirred a further $16 \mathrm{~h}$. The solution was then concentrated and co-evaporated with toluene. The residue was dissolved in $14 \%$ aqueous ammonia $(50 \mathrm{~mL})$, stirred $1 \mathrm{~h}$ at room temperature to hydrolyze potential $O$-acetyl groups. After 
concentration of the solution to half of its initial volume under vacuum, the aqueous phase was extracted 3 times with ethyl acetate to remove free $\mathrm{N}$-acetyl furfurylamine and concentrated. $\mathrm{N}$ acetamido- $N$-furfuryl-XGO was isolated in $90 \%$ yield $(998 \mathrm{mg}$ ) after purification by flash chromatography on silica gel $\left(\mathrm{CH}_{3} \mathrm{CN} / \mathrm{H}_{2} \mathrm{O} 7: 3 \mathrm{v} / \mathrm{v}\right) .{ }^{1} \mathrm{H} \mathrm{NMR}\left(400 \mathrm{MHz}, \mathrm{D}_{2} \mathrm{O}\right) \delta 7.51$ and 7.45 $(2 \mathrm{x} \mathrm{s}$, rotamers, $1 \mathrm{H}), 6.46-6.36(\mathrm{~m}, 2 \mathrm{H}), 5.53\left(\mathrm{~d}, J=9.0 \mathrm{~Hz}, 0.3 \mathrm{H}, \mathrm{H}_{1}{ }^{\mathrm{GlcN}}\right.$ rotamer $), 5.18(\mathrm{~m}$, $1 \mathrm{H}), 5.13\left(\mathrm{~d}, J=9.0 \mathrm{~Hz}, 1 \mathrm{H}, \mathrm{H}_{1}{ }^{\mathrm{GlcN}}\right.$ rotamer), $4.96(\mathrm{~m}, 2 \mathrm{H}), 4.62-4.55(\mathrm{~m}, 5 \mathrm{H}), 4.06-3.33(\mathrm{~m}$, $51 \mathrm{H}$ ), 2.30 and 2.26 ( $2 \mathrm{x} \mathrm{s}$, rotamers, $3 \mathrm{H}, \mathrm{NCOCH}_{3}$ ). The presence of the amide rotamers was confirmed by their disappearance at elevated temperature (323K) as observed by VT-NMR (see SI). (ESI) $m / z:[\mathrm{M}+\mathrm{Na}]^{+}: 1206.4$ (DP7), 1368.5 (DP8), 1530.5 (DP9). HR-MS $\mathrm{m} / z$ [M+Na] $]^{+}$ calculated for DP7; $\mathrm{C}_{46} \mathrm{H}_{73} \mathrm{NO}_{34} \mathrm{Na} ; 1206.3912$ Found $1206.3876, \mathrm{~m} / z[\mathrm{M}+\mathrm{Na}]^{+}$calculated for DP8; $\mathrm{C}_{52} \mathrm{H}_{83} \mathrm{NO}_{39} \mathrm{Na}$; 1368.4440 Found 1368.4401, $\mathrm{m} / z .[\mathrm{M}+\mathrm{Na}]^{+}$calculated for DP9; $\mathrm{C}_{58} \mathrm{H}_{93} \mathrm{NO}_{44} \mathrm{Na} ; 1530.4968$ Found 1530.4930 .

\section{LacEsterDox (16)}

$1(21 \mathrm{mg}, 0.022 \mathrm{mmol})$ was dissolved in DMF $(60 \mu \mathrm{l})$ and $N$-acetamido- $N$-furfuryl-Lactose ${ }^{40}$ $(28 \mathrm{mg}, 0.06 \mathrm{mmol})$ was added followed by water $(40 \mu \mathrm{l})$. The reaction mixture was stirred at $37{ }^{\circ} \mathrm{C}$ for 3 days. The solvents were removed by rotary evaporation and the crude material was dissolved in $\mathrm{CH}_{2} \mathrm{Cl}_{2} / \mathrm{MeOH}$, loaded on to silica and purified by flash column chromatography eluting with $10-20 \% \mathrm{H}_{2} \mathrm{O}$ in $\mathrm{CH}_{3} \mathrm{CN}$. 16 was isolated as a red solid (30 mg, 91\%) after lyophilization. HPLC method A (see SI); MS (ESI) $\mathrm{m} / \mathrm{z}:[\mathrm{M}+\mathrm{Na}]^{+}: 1443.6$; HR-MS $\mathrm{m} / \mathrm{z}$ $[\mathrm{M}+\mathrm{Na}]^{+}$calculated for $\mathrm{C}_{67} \mathrm{H}_{80} \mathrm{~N}_{4} \mathrm{O}_{30} \mathrm{Na}$ 1443.4755; Found 1443.4757.

\section{XGOEsterDox (17)}

1 (10 mg, $0.01 \mathrm{mmol}$ ) was dissolved in DMF (60 $\mu \mathrm{l})$ and $N$-acetamido- $N$-furfuryl-XGO 15 (66 $\mathrm{mg}, 0.05 \mathrm{mmol})$ was added followed by water $(60 \mu \mathrm{l})$. The reaction mixture was stirred at $37^{\circ} \mathrm{C}$ for 4 days. The solvents were removed by rotary evaporation and the crude was purified by two consecutive $\mathrm{C}_{18}$-columns (1g) eluting with a gradient of $0-100 \% \mathrm{MeOH}$ in water. The expected product 17 was isolated as a red solid $(8 \mathrm{mg}, 35 \%$ ) after lyophilization. HPLC method A (see $\mathrm{SI}$ ); (ESI) $\mathrm{m} / z:$ : $\mathrm{M}-\mathrm{H}]^{-}: 2140.9$ (DP7) , 2302.9 (DP8), 2464.9 (DP9). HR-MS $m / z$ [M+Na] ${ }^{+}$ calculated for DP7; $\mathrm{C}_{94} \mathrm{H}_{124} \mathrm{~N}_{4} \mathrm{O}_{52} \mathrm{Na} ; 2163.7029$ Found 2163.7079, $\mathrm{m} / z$ [M+Na] ${ }^{+}$calculated for DP8; $\mathrm{C}_{100} \mathrm{H}_{134} \mathrm{~N}_{4} \mathrm{O}_{57} \mathrm{Na} ; 2325.7607$ Found $2325.7495, \mathrm{~m} / z .[\mathrm{M}+\mathrm{Na}]^{+}$calculated for DP9; $\mathrm{C}_{106} \mathrm{H}_{144} \mathrm{~N}_{4} \mathrm{O}_{62} \mathrm{Na} ; 2487.8135$ Found 2487.8136.

\section{LactriPep(Alloc)Dox (18)}

13 (15 mg, $0.012 \mathrm{mmol}$ ) was dissolved in DMF (80 $\mu \mathrm{l})$ and $N$-acetamido- $N$-furfuryl-Lactose (16 mg, $0.035 \mathrm{mmol})$ was added followed by water $(40 \mu \mathrm{l})$. The reaction mixture was stirred at $37^{\circ} \mathrm{C}$ for 7 days. The solvents were removed by rotary evaporation and the crude material was dissolved in $\mathrm{CH}_{2} \mathrm{Cl}_{2} / \mathrm{MeOH}$, loaded on to silica and purified by flash column chromatography eluting with $10 \% \mathrm{H}_{2} \mathrm{O}$ in $\mathrm{CH}_{3} \mathrm{CN}$. The expected product 18 was isolated as a red solid $(12 \mathrm{mg}$, $58 \%$ ) after lyophilization. HPLC method A (see SI). MS (ESI) $m / z:[\mathrm{M}+\mathrm{Na}]^{+}: 1759.7$; HRMS $m / z[\mathrm{M}+\mathrm{Na}]^{+}$calculated for $\mathrm{C}_{83} \mathrm{H}_{100} \mathrm{~N}_{8} \mathrm{O}_{33} \mathrm{Na}: 1759.6290$, found: 1759.6302 .

\section{LactriPepDox (19)}

Following a modified procedure for Alloc deprotection, ${ }^{33} \mathbf{1 8}(7 \mathrm{mg}, 4.0 \mu \mathrm{mol})$ was dissolved in degassed $\mathrm{CH}_{2} \mathrm{Cl}_{2}: \mathrm{AcOH}(5: 1,600 \mu \mathrm{l})$. $\mathrm{Pd}\left(\mathrm{PPh}_{3}\right)_{4}(6 \mathrm{mg}, 5.2 \mu \mathrm{mol})$ was added. The reaction was stirred at $\mathrm{rt}$ in the dark and followed by TLC $\left(\mathrm{CH}_{2} \mathrm{Cl}_{2}: \mathrm{MeOH}: \mathrm{NH}_{4} \mathrm{OH}\right.$ 80:18:2). After $30 \mathrm{~min}$, the $\mathrm{CH}_{2} \mathrm{Cl}_{2}$ was removed and DEE (1 ml) was added which resulted in a red precipitation which was washed with DEE $(1 \mathrm{ml})$, EtOAc $(2 \times 1 \mathrm{ml})$ and then DEE $(1 \mathrm{ml})$ again. Ultrasonication and quick centrifugation was used in each wash cycle. The resulting red pellet was dried in a dessicator under low pressure. The resulting red solid (4 mg, 59\%) had a mass on ESI-MS and 
HRMS corresponding with the expected product 19 and consisted of one main compound with minor impurities on HPLC-UV. HPLC method A. MS (ESI) $\mathrm{m} / \mathrm{z}:[\mathrm{M}+\mathrm{H}]^{+}: 1653.6 \mathrm{HRMS} \mathrm{m} / \mathrm{z}$ $[\mathrm{M}+\mathrm{H}]^{+}$calculated for $\mathrm{C}_{79} \mathrm{H}_{97} \mathrm{~N}_{8} \mathrm{O}_{31}$ : 1653.6260, found: 1653.6244 .

\section{Enzymatic release of Doxorubicin}

Plasmin and human carboxylesterases were purchased from Sigma-Aldrich.

\section{Plasmin}

Following a protocol from the enzyme provider, ${ }^{47}$ a $100 \mu \mathrm{M}$ solution of $\mathbf{1 9}$ in phosphate buffer (pH 7.5) containing $100 \mathrm{mM}$ Lysine was incubated at $37^{\circ} \mathrm{C}$ with plasmin from human plasma $(15 \mu \mathrm{g} / \mathrm{ml})$. The reaction was followed by reversed phase HPLC (method B) by injecting $15 \mu 1$ aliquots from the reaction. The ratio of released doxorubicin over prodrug was calculated from integration of the peaks at $480 \mathrm{~nm}$ and plotted against time.

\section{Carboxylesterase}

A $100 \mu \mathrm{M}$ solution of ester linked prodrug (16 or 17) in Tris buffer $(50 \mathrm{mM}, \mathrm{pH} 7.4)^{48}$ was incubated at $37^{\circ} \mathrm{C}$ with either recombinant human carboxylesterase 1 isoform b $(100 \mu \mathrm{g} / \mathrm{ml})$ or recombinant human carboxylesterase $2(100 \mu \mathrm{g} / \mathrm{ml})$ expressed in baculovirus infected BTI insect cells . The reaction was followed by reversed phase HPLC (method B) by injecting 15 $\mu 1$ aliquots from the reaction. The ratio of released doxorubicin over prodrug was calculated from integration of the peaks at $480 \mathrm{~nm}$ and plotted against time.

\section{Growth inhibition assay}

The breast cancer cells MCF-7 were seeded at a density of $2 \times 10^{3}$ cells per well in 96-well plates. After $24 \mathrm{~h}$, cells were treated with an increasing concentration of compounds, from 0 to 100 $\mu \mathrm{M}$. Cells were incubated for $72 \mathrm{~h}$, and then, $20 \mu \mathrm{L}$ of MTS (Promega) was added per well for one hour at $37{ }^{\circ} \mathrm{C}$. The absorbance was read at $492 \mathrm{~nm}$ using a spectrophotometer (SPECTRAmax, Molecular Devices). $\mathrm{IC}_{50}$ values were obtained from the cytotoxicity curves using SOFTmax PRO software.

\section{Supporting Information description}

The SI contains NMR spectra and HPLC chromatograms.

\section{Acknowledgments}

This work was supported by the French National Research Agency (ANR) under the research grants Arcane (ANR-11-LABX-0003-01), Cellical (ANR-15-CE08-0033) and Glyco@Alps (ANR-15-IDEX-02). We acknowledge ICMG (FR 2607) platforms for granting access to the mass spectrometry and NMR facilities.

\section{Abbreviations}

Doxorubicin, Dox; Xyloglucan, XG; trifluoroacetic acid, TFA; dicyclohexylcarbodiimide, DCC; $\quad N$-methylmorpholine, $\quad \mathrm{NMM} ; \quad N, N$-diisopropylethylamine, $\quad$ DIPEA; (dimethoxy)triazinylmethylmorpholonium tetrafluoroborate, DMTMMBF 4 ; human carboxylesterase 2, hCE2; $p$-aminobenzyl alcohol, PABA; maleimidyl ester linked Doxorubicin, MalEsterDox; maleimidyl tripeptidyl linked Doxorubicin, MaltriPepDox

\section{References}


(1) Kim, S. H., and Kim, J. H. (1972) Lethal Effect of Adriamycin on the Division Cycle of HeLa Cells. Cancer Res. 32, 323-325.

(2) Pérez-Arnaiz, C., Busto, N., Leal, J. M., and García, B. (2014) New Insights into the Mechanism of the DNA/Doxorubicin Interaction. J. Phys. Chem. B 118, 1288-1295.

(3) Yang, F., Teves, S. S., Kemp, C. J., and Henikoff, S. (2014) Doxorubicin, DNA torsion, and chromatin dynamics. Biochim. Biophys. Acta, Rev. Cancer 1845, 84-89.

(4) Pommier, Y., Leo, E., Zhang, H., and Marchand, C. (2010) DNA Topoisomerases and Their Poisoning by Anticancer and Antibacterial Drugs. Chem. Biol. 17, 421-433.

(5) (1995) Doxorubicin-Induced Cardiotoxicity. N. Engl. J. Med. 333, 1359-1360.

(6) Srinivasarao, M., Galliford, C. V., and Low, P. S. (2015) Principles in the design of ligand-targeted cancer therapeutics and imaging agents. Nat. Rev. Drug. Discov. 14, 203-219.

(7) Barenholz, Y. (2012) Doxil ${ }^{\circledR}$ - The first FDA-approved nano-drug: Lessons learned. J. Controlled Release 160, 117-134.

(8) Waterhouse, D. N., Tardi, P. G., Mayer, L. D., and Bally, M. B. (2001) A Comparison of Liposomal Formulations of Doxorubicin with Drug Administered in Free Form. Drug Safety 24, 903-920.

(9) Mejia Oneto, J. M., Khan, I., Seebald, L., and Royzen, M. (2016) In Vivo Bioorthogonal Chemistry Enables Local Hydrogel and Systemic Pro-Drug To Treat Soft Tissue Sarcoma. ACS Cent. Sci. 2, 476-482.

(10) Amir, R. J., Popkov, M., Lerner, R. A., Barbas, C. F., and Shabat, D. (2005) Prodrug Activation Gated by a Molecular "OR" Logic Trigger. Angew. Chem., Int. Ed. Engl. 44, 4378-4381.

(11) Estrella, V., Chen, T., Lloyd, M., Wojtkowiak, J., Cornnell, H. H., Ibrahim-Hashim, A., Bailey, K., Balagurunathan, Y., Rothberg, J. M., Sloane, B. F., Johnson, J., Gatenby, R. A., and Gillies, R. J. (2013) Acidity Generated by the Tumor Microenvironment Drives Local Invasion. Cancer Res. 73, 1524.

(12) Tolcher, A. W., Sugarman, S., Gelmon, K. A., Cohen, R., Saleh, M., Isaacs, C., Young, L., Healey, D., Onetto, N., and Slichenmyer, W. (1999) Randomized Phase II Study of BR96-Doxorubicin Conjugate in Patients With Metastatic Breast Cancer. J. Clin. Oncol. 17, 478-478.

(13) Dubowchik, G. M., Firestone, R. A., Padilla, L., Willner, D., Hofstead, S. J., Mosure, K., Knipe, J. O., Lasch, S. J., and Trail, P. A. (2002) Cathepsin B-Labile Dipeptide Linkers for Lysosomal Release of Doxorubicin from Internalizing Immunoconjugates: Model Studies of Enzymatic Drug Release and Antigen-Specific In Vitro Anticancer Activity. Bioconjugate Chem. 13, 855-869.

(14) Houba, P. H. J., Boven, E., Meulen-Muileman, I. H. v. d., Leenders, R. G. G., Scheeren, J. W., Pinedo, H. M., and Haisma, H. J. (2001) A novel doxorubicin-glucuronide prodrug DOX-GA3 for tumour-selective chemotherapy: distribution and efficacy in experimental human ovarian cancer. Br. J. Cancer 84, 550-557.

(15) Legigan, T., Clarhaut, J., Renoux, B., Tranoy-Opalinski, I., Monvoisin, A., Berjeaud, J.-M., Guilhot, F., and Papot, S. (2012) Synthesis and Antitumor Efficacy of a $\beta$ Glucuronidase-Responsive Albumin-Binding Prodrug of Doxorubicin. J. Med. Chem. $55,4516-4520$.

(16) Connors, T. A., and Whisson, M. E. (1966) Cure of Mice bearing Advanced Plasma Cell Tumours with Aniline Mustard : the Relationship between Glucuronidase Activity and Tumour Sensitivity. Nature 210, 866-867.

(17) Rogers, J. C., and Kornfeld, S. (1971) Hepatic uptake of proteins coupled to fetuin glycopeptide. Biochem. Biophys. Res. Commun. 45, 622-629. 
(18) Benjamin G Davis, M. A. R. (2002) Drug delivery systems based on sugarmacromolecule conjugates. Curr. Opin. Drug Discovery Dev. 5, 279-288.

(19) Zhou, Q., Rutland, M. W., Teeri, T. T., and Brumer, H. (2007) Xyloglucan in cellulose modification. Cellulose 14, 625-641.

(20) Fink, H., Ahrenstedt, L., Bodin, A., Brumer, H., Gatenholm, P., Krettek, A., and Risberg, B. (2011) Bacterial cellulose modified with xyloglucan bearing the adhesion peptide RGD promotes endothelial cell adhesion and metabolism - a promising modification for vascular grafts. J. Tissue Eng. Regen. Med. 5, 454-463.

(21) Thijssen, V. L., Heusschen, R., Caers, J., and Griffioen, A. W. (2015) Galectin expression in cancer diagnosis and prognosis: A systematic review. Biochim. Biophys. Acta, Rev. Cancer 1855, 235-247.

(22) Ruvolo, P. P. (2016) Galectin 3 as a guardian of the tumor microenvironment. Biochim. Biophys. Acta, Mol. Cell Res. 1863, 427-437.

(23) Petrelli, A., Borsali, R., Fort, S., and Halila, S. (2015) Oligosaccharide-based block copolymers: Metal-free thiol-maleimide click conjugation and self-assembly into nanoparticles. Carbohydr. Polym. 124, 109-116.

(24) de Araújo, A. D., Palomo, J. M., Cramer, J., Köhn, M., Schröder, H., Wacker, R., Niemeyer, C., Alexandrov, K., and Waldmann, H. (2006) Diels-Alder Ligation and Surface Immobilization of Proteins. Angew. Chem., Int. Ed. Engl. 118, 302-307.

(25) Devaraj, N. K., Weissleder, R., and Hilderbrand, S. A. (2008) Tetrazine-Based Cycloadditions: Application to Pretargeted Live Cell Imaging. Bioconjugate Chem. 19, 2297-2299.

(26) Blackman, M. L., Royzen, M., and Fox, J. M. (2008) Tetrazine Ligation: Fast Bioconjugation Based on Inverse-Electron-Demand Diels-Alder Reactivity. J. Am. Chem. Soc. 130, 13518-13519.

(27) Petrelli, A., Samain, E., Pradeau, S., Halila, S., and Fort, S. (2017) Efficient Conjugation of Oligosaccharides to Polymer Particles through Furan/Maleimide Diels-Alder Reaction: Application to the Capture of Carbohydrate-Binding Proteins. ChemBioChem 18, 206-212.

(28) Xu, G., Zhang, W., Ma, M.K., McLeod, H. (2002) Human carboxylesterase 2 is commonly expressed in tumor tissue and is correlated with activation of irinotecan. Clin. Cancer Res. 8, 2605-2611.

(29) Carl, P. L., Chakravarty, P. K., and Katzenellenbogen, J. A. (1981) A novel connector linkage applicable in prodrug design. J. Med. Chem. 24, 479-480.

(30) Eisenbrand, G., Lauck-Birkel, S., and Tang, W. C. (1996) An Approach Towards More Selective Anticancer Agents. Synthesis 1996, 1246-1258.

(31) Chakravarty, P. K., Carl, P. L., Weber, M. J., and Katzenellenbogen, J. A. (1983) Plasmin-activated prodrugs for cancer chemotherapy. 2. Synthesis and biological activity of peptidyl derivatives of doxorubicin. J. Med. Chem. 26, 638-644.

(32) de Groot, F. M. H., de Bart, A. C. W., Verheijen, J. H., and Scheeren, H. W. (1999) Synthesis and Biological Evaluation of Novel Prodrugs of Anthracyclines for Selective Activation by the Tumor-Associated Protease Plasmin. J. Med. Chem. 42, 5277-5283.

(33) Barthel, B. L., Rudnicki, D. L., Kirby, T. P., Colvin, S. M., Burkhart, D. J., and Koch, T. H. (2012) Synthesis and Biological Characterization of Protease-Activated Prodrugs of Doxazolidine. J. Med. Chem. 55, 6595-6607.

(34) Gao, A. X., Liao, L., and Johnson, J. A. (2014) Synthesis of Acid-Labile PEG and PEGDoxorubicin-Conjugate Nanoparticles via Brush-First ROMP. ACS Macro Lett. 3, 854857.

(35) Tajbakhsh, M., Hosseinzadeh, R., Alinezhad, H., Ghahari, S., Heydari, A., and Khaksar, S. (2011) Catalyst-Free One-Pot Reductive Alkylation of Primary and Secondary 
Amines and N,N-Dimethylation of Amino Acids Using Sodium Borohydride in 2,2,2Trifluoroethanol. Synthesis 2011, 490-496.

(36) Setoi, H., Takeno, H., and Hashimoto, M. (1985) Enantiospecific total synthesis of (-)swainsonine: new applications of sodium borohydride reduction. J. Org. Chem. 50, 3948-3950.

(37) Kamiński, Z. J., Paneth, P., and Rudziński, J. (1998) A Study on the Activation of Carboxylic Acids by Means of 2-Chloro-4,6-dimethoxy-1,3,5-triazine and 2-Chloro4,6-diphenoxy-1,3,5-triazine. J. Org. Chem. 63, 4248-4255.

(38) Raw, S. A. (2009) An improved process for the synthesis of DMTMM-based coupling reagents. Tetrahedron Lett. 50, 946-948.

(39) Lockhoff, O. (1991) Glycolipids as Immunomodulators: Syntheses and Properties. Angew. Chem., Int. Ed. Engl. 30, 1611-1620.

(40) Priem, B., Peroux, J., Colin-Morel, P., Drouillard, S., and Fort, S. (2017) Chemobacterial synthesis of conjugatable glycosaminoglycans. Carbohydr. Polym. 167, 123128.

(41) York, W. S., van Halbeek, H., Darvill, A. G., and Albersheim, P. (1990) Structural analysis of xyloglucan oligosaccharides by 1H-n.m.r. spectroscopy and fast-atombombardment mass spectrometry. Carbohydr. Res. 200, 9-31.

(42) Guibé, F. (1998) Allylic protecting groups and their use in a complex environment part II: Allylic protecting groups and their removal through catalytic palladium $\pi$-allyl methodology. Tetrahedron 54, 2967-3042.

(43) Casey Laizure, S., Herring, V., Hu, Z., Witbrodt, K., and Parker, R. B. (2013) The Role of Human Carboxylesterases in Drug Metabolism: Have We Overlooked Their Importance? Pharmacotherapy 33, 210-222.

(44) Ryppa, C., Mann-Steinberg, H., Fichtner, I., Weber, H., Satchi-Fainaro, R., Biniossek, M. L., and Kratz, F. (2008) In Vitro and in Vivo Evaluation of Doxorubicin Conjugates with the Divalent Peptide E-[c(RGDfK)2] that Targets Integrin av $\beta 3$. Bioconjugate Chem. 19, 1414-1422.

(45) Gavande, N., Kim, H.-L., Doddareddy, M. R., Johnston, G. A. R., Chebib, M., and Hanrahan, J. R. (2013) Design, Synthesis, and Pharmacological Evaluation of Fluorescent and Biotinylated Antagonists of $\rho 1$ GABAC Receptors. ACS Med. Chem. Lett. 4, 402-407.

(46) de Groot, F. M. H., Broxterman, H. J., Adams, H. P. H. M., van Vliet, A., Tesser, G. I., Elderkamp, Y. W., Schraa, A. J., Jan Kok, R., Molema, G., Pinedo, H. M., and Scheeren, H. W. (2002) Design, Synthesis, and Biological Evaluation of a Dual Tumor-specific Motive Containing Integrin-targeted Plasmin-cleavable Doxorubicin Prodrug. Mol. Cancer Ther. 1, 901.

(47) http://www.sigmaaldrich.com/technical-documents/protocols/biology/enzymaticassay-of-plasmin-with-d-val-leu-lys-p-nitoanilide-dihydrochloride.html.

(48) Ross, M. K., and Borazjani, A. (2001) Enzymatic Activity of Human Carboxylesterases, in Current Protocols in Toxicology, John Wiley \& Sons, Inc. 


\section{Table of Contents graphics (TOC)}

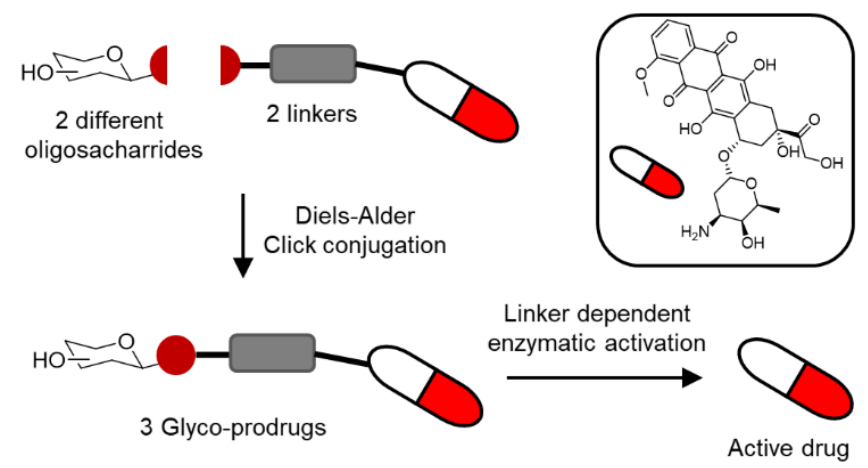

